\title{
Intergenerational differences in Russian color naming in the globalized era: linguistic analysis
}

\author{
Yulia A. Griber (10 ${ }^{1 凶}$, Dimitris Mylonas ${ }^{2} \&$ Galina V. Paramei ${ }^{3}$
}

The present study is an apparent-time analysis of color terms in Russian native speakers $(N=1927)$, whose age varied between 16 and 98 years. Stratified sampling was employed with the following age groups: 16-19, 20-29, and so on, with the oldest group of 70 years and over. Color names were elicited in a web-based psycholinguistic experiment (http:// colournaming.com). Participants labeled color samples $(N=606)$ using an unconstrained color-naming method. Color vocabulary of each age group was estimated using multiple linguistic measures: diversity index; frequency of occurrences of 12 Russian basic color terms (BCTs) and of most frequent non-BCTs; color-naming pattern. Our findings show intergenerational differences in Russian color-term vocabulary, color-naming patterns, and object referents. The CT diversity (measured by the Margalef index) progressively increments with speakers' juniority; the lexical refinement is manifested by the increasing variety of BCT modifiers and growing use of non-BCTs, both traditional and novel. Furthermore, the most frequent Russian non-BCTs sirenevyj "lilac", salatovyj "lettuce-colored", and birûzovyj "turquoise" appear to be the emerging BCTs. The greatest diversity and richness of CT inventory is observed in Russian speakers aged 20-59 years, i.e., those who constitute the active workforce and are enthusiastic consumers. In comparison, speakers of 60 and over manifest less diverse color inventory and greater prevalence of (modified) BCTs. The two youngest groups (16-29 years) are linguistic innovators: their color vocabulary includes abundant recent loanwords, predominantly from English and, not infrequently, CTs as nouns rather than adjectives. Moreover, Generation Z (16-19 years) tend to offer highly specific or idiosyncratic color descriptors that serve expressive rather than informative function. The apprehended dynamics of color naming in apparent time reflects intergenerational differences as such, but even more so dramatic changes of sociocultural reality in the post-Soviet era, whereby Russian speakers, in particular under 60 years, were/are greatly impacted by globalization of trade: new market product arrivals resulted in adoption of novel and elaboration of traditional CTs for efficient communication about perceived color

\footnotetext{
${ }^{1}$ Smolensk State University, Smolensk, Russia. ${ }^{2}$ New College of the Humanities at Northeastern University, London, UK. ${ }^{3}$ Liverpool Hope University, Liverpool, UK.凶email: y.griber@gmail.com
} 


\section{Introduction}

Synchronic heterogeneity of language in the speech community. Sociolinguistic studies provide evidence of synchronic heterogeneity of language, or apparent-time changes in the speech community, with such changes beginning with young people (cf. Labov, 1990; Tagliamonte and D’Arcy, 2009). The apparent-time construct assumes that language patterns mostly stabilize after childhood, and during the lifespan change relatively little (cf. D’Arcy, 2006; Tagliamonte and D'Arcy, 2009). Across languages, studies provide evidence that people of various age groups considerably differ in quantity and content of experience (Wulff et al., 2019), occupational status (Fisher et al., 2014), social networks (Wrzus et al., 2013), the use of the Internet and social media (Zickuhr and Madden, 2012), with all these factors having impact on their communication patterns and lexical inventory. In particular, maturing and aging are known to affect various levels of language processing: language variation (Pichler et al., 2018), lexical diversity and vocabulary size (Brysbaert et al., 2016), object naming ability and lexical retrieval (Connor et al., 2004), the structure of taxonomic categories and syntactic production skills (for reviews, see Burke and Shafto, 2004, 2008; Clark-Cotton et al., 2007; Thornton and Light, 2006).

Age-related differences in color-term inventory in the apparent time. To our knowledge, only a few studies explored age-related differences in color-term inventory and color-naming patterns in apparent time. Research into color terms (CTs) indicates that "stabilization of color-term inventory occurs in speakers before adulthood, though at different ages in different language communities. This stabilization is not an absolute stop for new CTsindeed new colors will wax and wane in popularity in society, and adult speakers can certainly innovate" (cf. Vejdemo, 2017, p. 144).

Here we review linguistic and anthropologic studies of intergenerational differences in color-term inventory; these employed an elicitation task and included the age range comparable with that in the present study age groups - from juveniles ( 10 years of age) and upwards. In a companion paper (Griber, Mylonas, \& Paramei, submitted) we review psycholinguistic studies of apparent-time changes in color category refinement of color space. The review is theoretically framed by the Berlin and Kay (1969/1991) hypothesis of universal color categories that emerge in a partly fixed order, from stage I, with two basic color terms (BCTs), 'light' and 'dark', through stage V, when a language possesses all 6 primary BCTs ('white', 'black', 'red', 'green', 'yellow', and 'blue'), to the final stage VII, at which also 5 secondary BCTs are present ('brown', 'orange', 'gray', 'purple', and 'pink'), thus, resulting in the inventory of 11 BCTs. Accordingly, individual languages are classified as being at a certain stage in the color-terminology expansion process, "having" a certain number of BCTs. Kay (1975) cautioned, however, that this is a simplification and that the assumption of a sequence of stages in the Berlin and Kay schema should not be interpreted as absolute for entire speaker communities: individual speakers can very well be at a different stage than the general consensus of the speaker group, but such speakers will always be spread out over adjacent stages in the sequence.

Intergenerational differences in color-term inventory: nonindustrialized cultures. To our knowledge, the earliest anthropologic studies of age-related variability of the inventory of BCTs are dated 1975 (scrutinized and summarized in Kay, 1975) and were carried out in three indigenous languages [Aguaruna (Peru), Binumarien (New Guinea), and Futunese (Polynesia)], all at stages III-V in the BCT evolutionary sequence, i.e., possessing between 4 and 6 BCTs (Berlin and Kay, 1969/1991). It was found that younger speakers (including juveniles, younger than 15 years old) were at stage $\mathrm{V}$ with 6 BCTs in their color vocabulary, compared to older speakers at stage III and stage IV (Kay, 1975, Table 1). These findings imply synchronic heterogeneity in the language community: compared to older speakers, younger speakers have more advanced BCT systems and are at later stages of the Berlin and Kay evolutionary sequence.

In non-industrialized societies the differences were found not solely in the number of BCTs, but also in the color vocabulary. Specifically, intergenerational variation reflected the process of westernization manifested by adopting new linguistic labels, with an apparent move away from traditional CTs towards the use of borrowed English terms, particularly in young speakers and those who have been to school. In West Futuna, juveniles used pidgin English terms iela 'yellow', plu 'blue', krin 'green', and praon 'brown' (Dougherty, 1977). Also, in Damara language (Namibia), stage VI, with transition to stage VII, loan terms from colonial languages were prevalent in adolescent speakers learned via the medium of education: groen 'green' and blou 'blue' (from Afrikaans), and green, blue, gray (from English), compared to rural adults (over 27 years) with no school education, who more frequently used traditional terms (Davies et al., 1997). Moreover in Setswana language (Botswana), children and young adults under 25 years used borrowed English terms as a wholesale substitution for traditional terms (Laws et al., 1995).

Intergenerational differences in color vocabulary: European languages. Color vocabulary of different age groups was also explored in some European languages with elaborated, 11-BCT color inventory, i.e., at stage VII of the Berlin and Kay (1969/ 1991) classification. Several general findings emerge that are summarized below. Notably, intergenerational variation in CTs appear to be particularly enhanced when one compares older rural and younger urban speakers.

Uncertainty of lexical denotation of PURPLE and ORANGE areas. Recurring observations relate to PURPLE and ORANGE color

Table 1 Age and gender characteristics for individual age cohorts of the participant sample.




space areas, lexical labels of which emerge at Stage VII, i.e., late at the BCT evolution. For Polish (at the end of the 1940s) Zaręba (1954, p. 138) found that elderly speakers did not understand the meaning of BCTs fioletowy 'purple' and pomarańczowy 'orange' used by young speakers with high consensus. The uncertainty of naming PURPLE and ORANGE areas by rural speakers of older generations (aged around 70 years) is echoed by recent findings for Galician. Whereas young speakers with high consensus use violeta 'purple', in one village some elderly respondents named purple color using object-referent non-BCTs da cor do viño 'wine color', or lila or malva (Villanueva Gesteira, 2009); in another village elderly people used up to four different terms: lila, violeta, morado and malva, and half of them named a purple object azul 'blue' (Teixeira, 2019). Similarly, for 'orange', young speakers use laranxa or naranxa (Galicianization of Spanish naranja); in comparison, the elderly named an orange sample butano (alluding to locally delivered butane gas bottles painted in vivid orange) or rubio, roxo 'red' (Villanueva Gesteira, 2009); again, in another village they named an orange object naranja/laranxa, or tella (roof tile), or labeled it 'yellow' or 'brown' (Teixeira, 2019).

Lexical replacement in some color space areas. Several studies revealed intergenerational flux in labeling basic color categories (BCCs), whereby two contenders of BCTs "fight for supremacy" (cf. Vejdemo, 2017, p. 144). In Polish, in the BLUE area, older generation's jasny was replaced by young generation's niebeski 'blue' (BCT) and non-basic błękitny (Zaręba, 1954), the two nearsynonyms that in modern Polish have different connotations (Stanulewicz, 2010).

In French, the historically older term for 'brown' brun is being supplanted by more recent marron (Forbes, 2006). Specifically, brun was found to be used more often by those in the 61-65 years age group, compared to younger speakers, aged 12-30 years, who predominantly used marron, while the youngest, aged 3-11 years, offered only marron to name brown items. This apparent-time change mimicked the real-time change in usage of the two 'brown' terms recorded between 1975 and 1995 (Forbes, 2006; cf. Tables 2 and 3).

In Galician, the older generation names all brown objects castaño, compared with middle-aged and young generations who use marrón (Spanish loanword), reserving non-BCT castaño for naming color of eyes and hair (Villanueva Gesteira, 2009; Teixeira, 2019). Lexical replacement is also observed in the RED area: the elderly's historically Galician rubio (Villanueva Gesteira, 2009) or vermello and encarnado (Teixeira, 2019) have been supplanted by roxo or Spanish loanword rojo.

In Swedish, for two groups of speakers, aged 19-35 and 55-67 years, Vejdemo $(2017,2018)$ found intergenerational changes across the whole color gamut manifested by a general weakening of frequency of use (attenuation) of some CTs. In particular, she revealed ongoing lexical replacement processes pronounced in PINK and PURPLE areas of color space: in PINK area, the older group's skär is supplanted by younger speakers' rosa; in PURPLE area, the older group's violett is disappearing in the younger generation's vocabulary, who predominantly use lila.

Intergenerational differences in color-naming patterns. Several studies found age-related differences in color-naming patterns, with the recurring finding, for various languages, of a richer color lexicon in speakers of older generations. Older Swedes were found to use many more modifiers and color compounds than younger speakers, who were less imaginative in their modifiers (using mostly 'light' and 'dark') (Vejdemo, 2018). British English speakers over 40 years used more non-BCTs (e.g., magenta) or 'fancy' color names (e.g., jade green), compared with those under 30 years (Simpson and Tarrant, 1991). This observation is echoed by Ryabina's (2009) findings for two age groups, 9-15 and 38-77 years, of speakers of Udmurt (Finno-Ugric language spoken in northern regions of European Russia): the elder group offered many more elaborate terms, such as qualified BCTs (e.g., 'greenish blue'), non-BCTs ('mauve'), qualified fancy terms (i.e., 'carrot yellow'). Richness of color vocabulary was also demonstrated for Russian speakers in their $40 \mathrm{~s}$ and $50 \mathrm{~s}$; however, from 60 years of age the proportion of object-derived color names declined (Griber et al., 2020).

Also noteworthy is the contrast in the kind of non-BCTs and, in particular, their object referents, between older rural and younger speakers. For several Caucasus languages in remote mountain villages, Samarina (2007) found that, rather than using abstract terms, elderly people produced object-derived CTs referring to indigenous food products (e.g., 'yellow as yolk'), plants ('chestnut'), wild animals and birds ('color of pigeon neck'), and natural materials employed for obtaining dyes ('madder', 'color of wood resin'). Similarly, in Galician the elderly used local natural referents to name 'gray' as aborrallado [from borralla 'ashes' (Villanueva Gesteira, 2009)], while elderly Udmurt used terms referring to indigenous plants (e.g., 'globeflower') (Ryabina, 2009).

In comparison, frequent in the young generation's parlance are "fancy" non-BCTs (cf. Biggam, 2012) - that serve to convey a color shade more precisely. It is worth noting that object-derived (metonymic) non-BCTs imply color references transparent for this generation's speakers-but not necessarily to older speakers: Zaręba (1954) reported that (in late 1940s) the elderly Polish had difficulty understanding the youngers' non-BCTs 'lemoncolored', 'sapphire', 'claret', 'celadon-colored' or 'bronze'. The younger also frequently use "conventional" loanwords, whose denotative meaning is transparent, although not object-derived (e.g., pink in Swedish and other Germanic languages) (Vejdemo, 2018).

Aging effects: color discrimination vs. color appearance. We conclude the overview with a remark that older speakers' lexical changes in CTs might also reflect changes in color vision caused by aging of the eye ocular media. Specifically, increased yellowness and opaqueness of the crystalline lens, pronounced from 60 years onwards, results in deterioration of chromatic discrimination, in particular, in the short wavelength part of the spectrum (Barbur and Rodriguez-Carmona, 2015; Paramei and Oakley, 2014). These aging processes manifest by poorer discrimination of green, blue, bluish green, violet, and orange colors (PérezCarpinell et al., 2006).

The relationship between chromatic sensitivity and color appearance is, however, not straightforward: the differences in spectral sensitivity often have surprisingly little effect on how people report their color sensations. Thus, despite viewing stimuli through lenses that filter the spectrum in very different ways, the

Table 2 Number of tokens and word types in the subsamples of respondents in different age groups.

\begin{tabular}{lcccccccc} 
& Total & $\mathbf{1 6 - 1 9}$ & $\mathbf{2 0 - 2 9}$ & $\mathbf{3 0 - 3 9}$ & $\mathbf{4 0 - 4 9}$ & $\mathbf{5 0 - 5 9}$ & $\mathbf{6 0 - 6 9}$ & $\mathbf{7 0}+$ \\
\hline Tokens & 55,515 & 2176 & 11,580 & 10,286 & 7107 & 7297 & 6192 & 3864 \\
Word types & 3128 & 354 & 1299 & 1034 & 840 & 740 & 385 \\
\hline
\end{tabular}


Table 3 The first 30 most frequent color names elicited in individual age groups.

\begin{tabular}{|c|c|c|c|c|c|c|c|}
\hline Rank & $16-19$ & $20-29$ & $30-39$ & $40-49$ & $50-59$ & $60-69$ & $70+$ \\
\hline 1 & fioletovyj & fioletovyj & fioletovyj & fioletovyj & rozovyj & zelënyj & rozovyj \\
\hline 2 & zelënyj & rozovyj & rozovyj & zelënyj & fioletovyj & fioletovyj & zelënyj \\
\hline 3 & sinij & zelënyj & zelënyj & rozovyj & zelënyj & rozovyj & fioletovyj \\
\hline 4 & rozovyj & sinij & $\operatorname{sinij}$ & $\sin i j$ & goluboj & $\sin i j$ & $\sin i j$ \\
\hline 5 & goluboj & goluboj & goluboj & goluboj & $\operatorname{sinij}$ & goluboj & koričnevyj \\
\hline 6 & koričnevyj & koričnevyj & sirenevyj & koričnevyj & sirenevyj & koričnevyj & goluboj \\
\hline 7 & seryj & sirenevyj & koričnevyj & sirenevyj & žëltyj & seryj & seryj \\
\hline 8 & sirenevyj & oranževyj & žëltyj & seryj & koričnevyj & žëltyj & žëltyj \\
\hline 9 & žëltyj & žëltyj & seryj & žëltyj & seryj & krasnyj & krasnyj \\
\hline 10 & birûzovyj & birûzovyj & birûzovyj & krasnyj & oranževyj & sirenevyj & oranževyj \\
\hline 11 & oranževyj & seryj & salatovyj & birûzovyj & salatovyj & bordovyj & čërnyj \\
\hline 12 & krasnyj & salatovyj & krasnyj & salatovyj & krasnyj & oranževyj & sirenevyj \\
\hline 13 & salatovyj & krasnyj & oranževyj & oranževyj & birûzovyj & čërnyj & salatovyj \\
\hline 14 & bolotnyj & bordovyj & bordovyj & čërnyj & čërnyj & birûzovyj & beževyj \\
\hline 15 & tëmno-sinij & čërnyj & fuksiâ & bordovyj & bordovyj & salatovyj & belyj \\
\hline 16 & bordovyj & tëmno-sinij & čërnyj & fuksiâ & malinovyj & belyj & bordovyj \\
\hline 17 & $\begin{array}{l}\text { tëmno- } \\
\text { zelënyj }\end{array}$ & fuksiâ & beževyj & lilovyj & belyj & persikovyj & birûzovyj \\
\hline 18 & purpurnyj & $\begin{array}{l}\text { tëmno- } \\
\text { zelënyj }\end{array}$ & malinovyj & malinovyj & beževyj & beževyj & persikovyj \\
\hline 19 & beževyj & $\begin{array}{l}\text { tëmno- } \\
\text { fioletovyj }\end{array}$ & $\begin{array}{l}\text { svetlo- } \\
\text { zelënyj }\end{array}$ & beževyj & tëmno-sinij & malinovyj & bolotnyj \\
\hline 20 & persikovyj & bolotnyj & $\begin{array}{l}\text { tëmno- } \\
\text { fioletovyj }\end{array}$ & $\begin{array}{l}\text { tëmno- } \\
\text { zelënyj }\end{array}$ & bolotnyj & $\begin{array}{l}\text { tëmno- } \\
\text { zelënyj }\end{array}$ & tëmno-sinij \\
\hline 21 & čërnyj & beževyj & bolotnyj & $\begin{array}{l}\text { svetlo- } \\
\text { zelënyj }\end{array}$ & persikovyj & tëmno-sinij & $\begin{array}{l}\text { tëmno- } \\
\text { zelënyj }\end{array}$ \\
\hline 22 & $\begin{array}{l}\text { tëmno- } \\
\text { fioletovyj }\end{array}$ & malinovyj & $\begin{array}{l}\text { tëmno- } \\
\text { zelënyj }\end{array}$ & belyj & $\begin{array}{l}\text { svetlo- } \\
\text { zelënyj }\end{array}$ & gorčičnyj & $\begin{array}{l}\text { svetlo- } \\
\text { zelënyj }\end{array}$ \\
\hline 23 & lilovyj & purpurnyj & tëmno-sinij & gorčičnyj & $\begin{array}{l}\text { tëmno- } \\
\text { fioletovyj }\end{array}$ & bolotnyj & malinovyj \\
\hline 24 & fuksiâ & lilovyj & lilovyj & $\begin{array}{l}\text { tëmno- } \\
\text { fioletovyj }\end{array}$ & $\begin{array}{l}\text { tëmno- } \\
\text { zelënyj }\end{array}$ & $\begin{array}{l}\text { svetlo- } \\
\text { zelënyj }\end{array}$ & fuksiâ \\
\hline 25 & malinovyj & gorčičnyj & gorčičnyj & $\begin{array}{l}\text { ârko- } \\
\text { rozovyj }\end{array}$ & gorčičnyj & $\begin{array}{l}\text { tëmno- } \\
\text { fioletovyj }\end{array}$ & $\begin{array}{l}\text { tëmno- } \\
\text { rozovyj }\end{array}$ \\
\hline 26 & gorčičnyj & khaki & mâtnyj & khaki & $\begin{array}{l}\text { svetlo- } \\
\text { koričnevyj }\end{array}$ & $\begin{array}{l}\text { svetlo- } \\
\text { fioletovyj }\end{array}$ & $\begin{array}{l}\text { svetlo- } \\
\text { rozovyj }\end{array}$ \\
\hline 27 & belyj & belyj & $\begin{array}{l}\text { svetlo- } \\
\text { fioletovyj }\end{array}$ & $\begin{array}{l}\text { svetlo- } \\
\text { fioletovyj }\end{array}$ & fuksiâ & kirpičnyj & slivovyj \\
\hline 28 & $\begin{array}{l}\text { sero- } \\
\text { goluboj }\end{array}$ & persikovyj & belyj & $\begin{array}{l}\text { tëmno- } \\
\text { rozovyj }\end{array}$ & lilovyj & $\begin{array}{l}\text { ârko- } \\
\text { rozovyj }\end{array}$ & mâtnyj \\
\hline 29 & okhra & $\begin{array}{l}\text { ârko- } \\
\text { rozovyj }\end{array}$ & $\begin{array}{l}\text { ârko- } \\
\text { rozovyj }\end{array}$ & tëmno-sinij & $\begin{array}{l}\text { sero- } \\
\text { goluboj }\end{array}$ & fuksiâ & $\begin{array}{l}\text { tëmno- } \\
\text { fioletovyj }\end{array}$ \\
\hline 30 & $\begin{array}{l}\text { cvet } \\
\text { morskoj } \\
\text { volny }\end{array}$ & $\begin{array}{l}\text { svetlo- } \\
\text { fioletovyj }\end{array}$ & purpurnyj & bolotnyj & khaki & khaki & $\begin{array}{l}\text { svetlo- } \\
\text { koričnevyj }\end{array}$ \\
\hline
\end{tabular}

In bold black are the $12 \mathrm{BCTs}$. High-ranking non-BCTs are in bold and rendered in the corresponding colors. Cells with the dominant color names are marked in gray.

young and old observers choose similar stimuli for different hues (Hardy et al., 2005; Lindsey and Brown, 2002) or for white (Werner and Schefrin, 1993). The color-naming pattern in older observers was found to be best modeled when two processes are combined-filtering and compensation based on white normalization (Lillo et al. (2012). This is in accord with Wuerger's (2013) conclusion that throughout the lifespan there unfolds a compensatory mechanism that keeps color appearance largely intact even as humans age. These recent findings echo the contention of Enoch et al. (1999), who graphically titled their article "Forever young". The lens opaqueness and decrease in pupil size, increasing with age, also cause diminishing of retinal illuminance, which results in an overall "darkening" of perceived colors and a shift in their hue, whereby reddish and greenish components predominate over bluish and yellowish ones (Knoblauch et al., 1987).

Russian basic and frequent non-basic color terms. Forestalling our intergenerational analysis, we observe that in Russian the inventory of CTs is very rich and variegated, as attested by numerous linguistic studies, with the list in no case being exhaustive (Bakhilina, 1975; Frumkina, 1984; Frumkina and Mikhejev, 1996; Kul'pina, 2001, 2007, 2019; Rakhilina, 2007a, 
2007b, 2000/2008; Vasilevich, 1981; Vasilevich et al., 2005; Vasmer, 1953). Russian has 12 BCTs: along with counterparts of 10 BCTs of the Berlin and Kay stage VII: belyj 'white', čërnyj 'black'; krasnyj 'red', zelënyj 'green', žëltyj 'yellow', koričnevyj 'brown', oranževyj 'orange', fioletovyj 'purple', rozovyj 'pink', and seryj 'gray', it has two terms for 'blue', sinij 'dark blue' and goluboj 'light blue' (Davies and Corbett, 1994; Paramei, 2005, 2007).

Russian also has a rich inventory of non-BCTs, some of which have high usage frequency (Paramei et al., 2018), including three, sirenevyj 'lilac', salatovyj 'lettuce-colored', and birûzovyj 'turquoise', that likely are emerging as basic. Furthermore, monolexemic color names, like other Russian adjectives, can be modified by various diminutive or expressive suffixes (-ovat-, -en'k-), which enable conveyance of nuances of CT meanings (Astakhova, 2014; Kul'pina, 2001, 2007; Vasilevich et al., 2005). Moreover, Russian speakers frequently combine monolexemic CTs, and use them with various modifiers and qualifiers (e.g., Kul'pina, 2001, 2007; Paramei et al., 2018), are inventive in resorting to a great variety of object referents (Griber et al., 2018a) and producing complex constructions for aestheticization of color relations (e.g., cveta krepkogo čaja 'color of strong tea'; Kul'pina, 2007).

Aims of the present study. In the present study we investigate intergenerational differences in color naming in an extensive sample of native Russian speakers aged between 16-98 years, stratified into seven age groups. Responses were collected in an online color-naming experiment over two years (2018-2020). We focused on apparent-time changes in color vocabulary and colornaming patterns. In a companion paper (Griber, Mylonas, \& Paramei, in preparation) we elaborate on psycholinguistic analysis by focusing on denotative meanings of BCCs and a juniority effect of color inventory replenishment and lexical refinement of color space observed in modern Russian.

Our particular interest was in sociocultural influences on changes in color-term inventory in younger cohorts of Russian respondents, Millennials (born between 1981 and mid-1990s) and Generation Z (Gen Z, born between mid-1990s and early 2000s) (Strauss and Howe, 1991, 2000). These generations grew up or were born after 1991, i.e., the dissolution of the Soviet Union, following which Russia became open to abundant Western products. Accordingly, Millennials' and Gen Z's acquisition and consolidation of color lexicon occurred in the period of dramatic transformation in the "chromatic diet"-environmental color statistics in the man-made world of Russians due to exposure to novel colors and dyes (cf. Lindsey and Brown, 2019; Zaslavsky et al., 2020), and their names (predominantly English loanwords).

\section{Methods}

Participants. Respondents were native speakers of Russian ( $N=1927 ; 1307$ females), residents of various regions of the Russian Federation, both in its European and Asian parts. Participants were recruited in 2018-2020 via social media and wordof-mouth, with further snowball method of sampling, and provided with the weblink to an online experiment. The participants were aged between 16-98 years, i.e., born between 1927 and 2003. The number of respondents in each age year is presented in Fig. 1.

The participant sample was drawn using a combination of several sampling schemes (Griber and Dvoinev, 2018). At an initial stage $(n<1000)$, a simple random sampling was pursued. This was followed by a stratified sampling, distinguishing seven age groups: 16-19, 20-29, 30-39 years, and so on, with the eldest group being 70 years and over (Table 1). We singled out the group of 16-19-year-old bearing in mind that the frequency of usage of incoming (innovative) linguistic forms is highest in



Fig. 1 The number of participants for each age year in the sample (in red; left axis). The number of unique elicited responses, color descriptors for the corresponding age year is in blue (right axis).

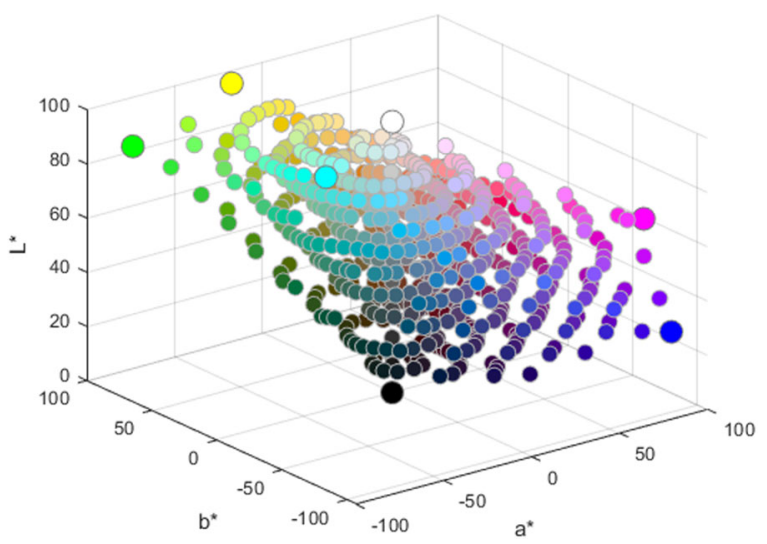

Fig. 2 Stimuli in the color-naming experiment constrained by the SRGB gamut and plotted in $\mathbf{C I E L}^{\star} \mathbf{a}^{\star} \mathbf{b}^{\star}$ space. Enlarged circles denote eight color samples at the corners of the sRGB cube.

adolescence peaking at $\sim 17$ years of age (Tagliamonte and D'Arcy, 2009). Further, the two youngest respondent groups (16-19, 20-29) included those of Gen Z, born between 1996 and 2003; the Millennials, born between 1981 and 1995, constituted part of the 20-29 and the 30-39 age group. The middle-aged groups, 40-49 and 50-59, included Generation X respondents (born between 1965-1980). (Henceforth, for brevity, in indicating the age groups the word "years" is omitted.)

All respondents were screened for possible color vision deficiencies with a web-based Dynamic Color Vision Test developed at the City, University of London (Barbur, 2004), implemented as part of the online color naming experiment. Data of those who revealed color-vision abnormality were excluded from the analysis.

Participants were not required to identify themselves, apart from their age, gender and other demographic characteristics indicated above, so the collected data were not linked to individuals. Participation was voluntary, did not put any strain of power on the participants. They were informed that they could withdraw from the experiment at any time. The experimental procedure complied with the ethical principles of the Declaration of Helsinki.

Color stimuli. Color samples $(N=606)$ were approximately uniformly distributed in the Munsell Renotation Dataset with an addition of 8 color samples at the corners of the sRGB cube and 9 neutral samples (Fig. 2). 
Design of the web-based experiment and procedure. Color names were elicited in a web-based psycholinguistic experiment (http://colournaming.com). Detailed information on the design and interface of the experiment can be found in our previous works (Mylonas and MacDonald, 2010; Paramei et al., 2018). Participants were presented with randomly selected color samples, one at a time, and requested to name the color by inputting their response in Russian using a keyboard with the Cyrillic alphabet. An unconstrained color-naming method was employed: participants were free to use any color descriptor as either a single word, or a compound, or term(s) with modifiers or qualifiers. Responses were recorded verbatim. In addition, information was collected about the participant's residency, nationality, confirmation of Russian as the native language, and information on mastering (if any) other language(s), level of education, age, gender, and color competence (professional, hobby, layperson; for "color expertize" effects, see Griber and Paramei, 2019).

Data cleaning. The obtained list of color descriptors appeared to contain many typographical or spelling errors and, occasionally, words from other languages rendered in Latin characters. For this reason, the raw data were subjected to a multistep cleaning that included checking and correction of the errors (e.g., хакu [khaki] 'khaki' vs. *хакки or *хаке; фиолетовый [fioletovyj] 'purple' vs. * фиотетовый or *фирлетовый). Further, we excluded abbreviated responses (e.g., роз [roz], abbreviation of розовыц 'pink'), vernacular acronyms (e.g., dcn [dsp], acronym of drevesno-stružečnaja plita 'particleboard'), numerical terms, or color terms written in the Cyrillic alphabet but non-Russian (e.g., in Ukrainian or Belarusian).

The algorithm of data cleaning consisted of three main steps (Samoilova and Griber, 2019). First, from a database we retrieved all unique names by using Structured Query Language (SQL) in Microsoft Office Access Program. The resulting list included 4770 terms, many of which were misspelled or were not color names. This step resulted in reducing the list names by almost twelve times. Second, the cleaned list of terms was checked manually (by the first author), to identify misspelled CTs (e.g., бирюзовыци [birûzovyj] 'turquoise' vs. *берюзовыı̆); a replacement table was compiled with the corresponding correct spellings. Third, instructed by the table, replacement of the misspelled CTs in the dataset was accomplished by using Visual Basic for Application (VBA) macros in Excel.

The final stage of data cleaning involved removing distinction between identical terms rendered in uppercase and lowercase letters (e.g., KRASNYJ and krasnyj 'red'). A further reduction was achieved by merging regular inflection forms with different endings that in Russian distinguish masculine $(\mathrm{m})$ and feminine (f) forms (e.g., krasnyj 'red' (m), krasnaya 'red' (f)), as well as singular and plural forms of nouns indicating object referents (e.g., cvet vasil'ka 'color of a cornflower', cvet vasil'kov 'color of cornflowers'). For the ensuing analysis of the cleaned list, the elicited Russian color names were transliterated into Latin letters using a free online transliterator (https://translit.cc).

Defining "tokens", “word types", and "lemmas" in the lexical material. Following Brysbaert et al.'s (2016) glossary, the total number of color names (responses) in the dataset are referred to as "tokens", whereas unique word forms (e.g., a polysemic descriptor; a variation in the order of a CT and its modifier, or of modifier's ending) are denoted as "word types". The word types were identified alphabetically and lemmatized, i.e., limited to those that are regarded as real words by Russian speakers (e.g., near-synonyms with a similar meaning 'dark purple'-tëmnofioletovyj, tëmno-tëmno-fioletovyj, tëmnyj fioletovyj, fioletovyj tëmnyj-were considered as different word types). Finally,



Fig. 3 Percentage of occurrences of color-term word types. White bars represent occurrence of word types in color vocabulary of participants of different age groups in general; red bars indicate occurrence of the 12 Russian BCTs and their derivatives.

"lemma" is the word's canonical form, the basis for its all inflected forms. Groups of lemmas that are morphologically related were treated as a word family. For the total sample of Russian respondents, the refined dataset consisted of 55,515 responses (tokens) and contained 3128 word types (Table 2).

\section{Data analysis}

Measures for intergroup comparison. For each age group, we estimated multiple linguistic measures of color vocabulary:

(1) diversity index of color lexicon (see "Richness of color lexicon");

(2) clustering of age groups' color lexicons ("Ward clustering method");

(3) high-frequency color names and dominant word types;

(4) occurrence of the 12 Russian BCTs;

(5) BCT modified and compounded forms;

(6) number of words in color descriptors;

(7) object as color-term referents;

(8) incidence of models "cveta X" 'color of X' and " $X$ " (where X is a noun denoting an object).

Richness of color lexicon. To estimate heterogeneity of color lexicon in each age group, we calculated the Margalef diversity index commonly used in ecology (see, e.g., Yeom, and Kim, 2011). This measure enabled assessment of richness of color lexicon, i.e., abundance of unique color descriptors in each age group's response set). The Margalef index D (Margalef, 1958) was calculated as:

$$
D=(S-1) / \ln N
$$

where $S$ is the number of word types (here: unique word forms observed in the dataset) and $N$ is the total number of tokens (here: total number of responses) in the dataset. The Margalef index good discriminant ability, it strongly depends, however, on the sample size (Gamito, 2010).

Ward clustering method. Similarity of color inventories between individual age groups and across all was assessed using the method of agglomerative hierarchical clustering implemented in a program developed in $\mathrm{R}$ in Microsoft $\mathrm{R}$ Open 3.5 environment. Distances between clusters were calculated using the Ward's minimum variance criterion (Ward, 1963). For visualization of the outcome, the ggplot2 package was used.

\section{Results}

Color lexicon: richness and diversity. The apparent-time analysis shows that richness and diversity of Russians' color vocabulary remain relatively stable up to the mature age; however, after 60 years of age its richness decreases, as measured by percentage of CT word types (Fig. 3). The youngest respondents 
revealed the highest number of word types, $n_{16-19}=354(16 \%$ from the total number of responses in this age group); in comparison, the oldest participants revealed the lowest, among all age groups, diversification of color-term inventory, $n_{70+}=209$ (5.43\% from the total number of responses in this age group). The CT abundancy contrast is even more telling if one takes into account that there were 95 respondents in the 16-19 group compared to 202 respondents in the $70+$ group (Table 1 ).

The Margalef diversity index (Fig. 4) indicates noticeable differences in richness of color vocabulary between individual age groups: respondents under 40 possess high-diversity color lexicon; the diversity is lower in the 40-59-year-old, and decreases in those over 60 years of age, as reflected by a steep lowering of the index from 40 years onwards. Since the Margalef index is sensitive to the sample size, the intergroup differences apparently also reflect lower numbers of respondents in the youngest and the two eldest groups.

In addition to the age group estimates, we explored performance of the Margalef index for each year of life while highlighting intergenerational differences. Figure 5 demonstrates that the relative number of color word types is highest for respondents of the three



Fig. 4 The Margalef diversity index. Richness of color vocabulary of the participants of the seven age groups. young(er) generations-Gen Z, Millennials and Generation X; it is noticeably lower and steadily decreases with age in the generations of 50 and over. Figure 5 also prompts that color lexicon is greatly diversified in the three young(er) generations, whereas it has low variation in the two older generations.

Similarity of color lexicons between age groups. To complement the measure of color-term diversity, we also assessed similarity of color lexicon between the seven age groups, by applying the hierarchical Ward's (1963) clustering method. The dendrogram (Fig. 6) shows that speakers aged 20-29 and 30-39 (Millennials) fall into one cluster. Another cluster includes respondents born between 1950 and 1979, i.e., those aged 40-49, 50-59 and 60-69, with the mature group aged 70 and above abutting to this cluster. Not unexpectedly, the 16-19 group (Gen $\mathrm{Z}$ ), who grew up in the very different post-Soviet socio-economic environment, appears quite different from all other age groups.

High-frequency color names and dominant word types. For each age group, we identified and ranked 30 most frequent color names (Table 3). As expected, all lists include the 12 Russian

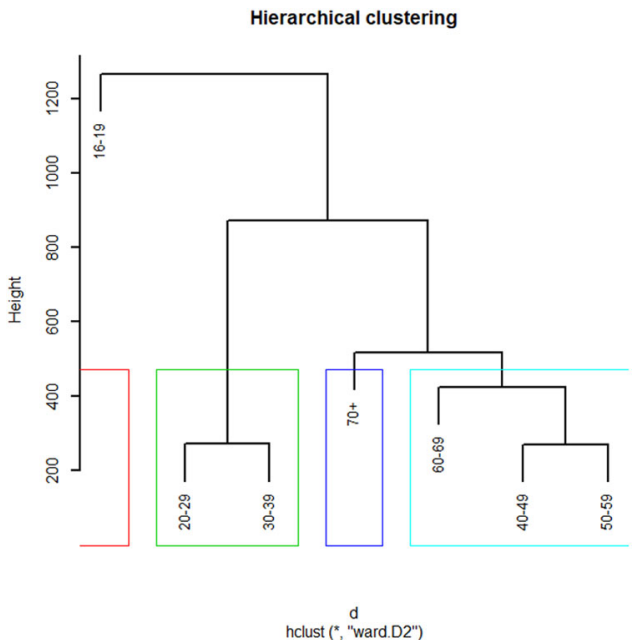

Fig. 6 Similarity of color lexicons. Dendrogram representing age group clusters.



Fig. 5 The Margalef diversity index (D). Richness of color vocabulary in participants of individual age years. 


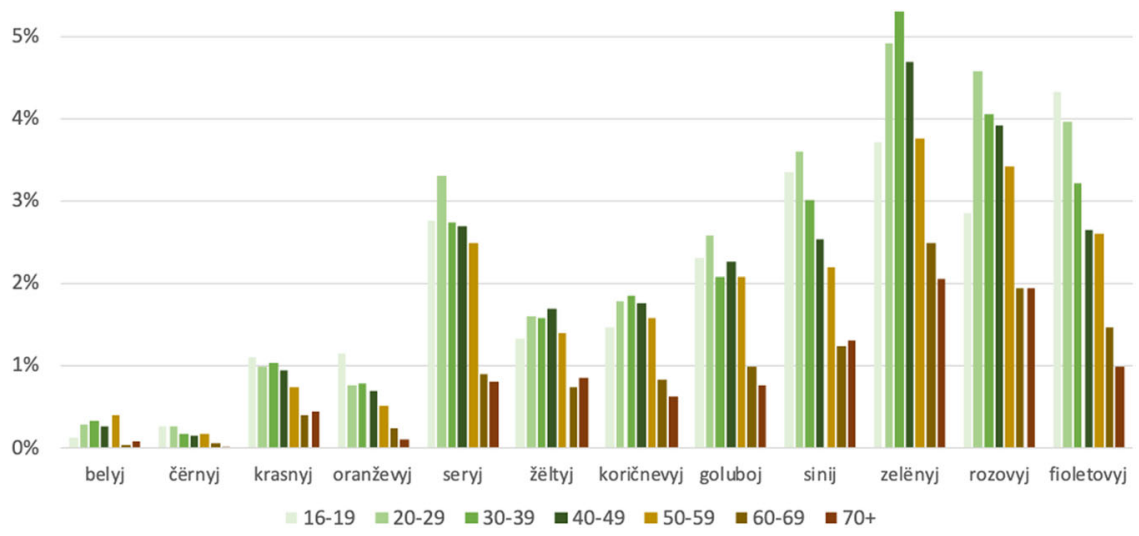

Fig. 7 Percentage of occurrences of the 12 Russian BCTs in different age groups. The BCTs are ordered according to the response frequency, from lowest (left) to highest (right).

BCTs (rendered in black bold). Note that in all lists achromatic BCTs čërnyj 'black' and belyj 'white' are ranked below 12, which is likely to reflect sparcity of the corresponding colors in the employed set of self-luminous stimuli rather than the CT frequencies as such. The lists in Table 3 also include other word types - modified BCTs (considered below, in "Word families of the 12 Russian BCTs: derived, modified and compounded forms") and multiple non-BCTs (addressed in detail in "Age differences in frequent Russian non-BCTs").

Along with the list of most frequent CTs (word types), for each age group we also identified dominant color name types, i.e., those that constitute at least $50 \%$ of all tokens). We observe the juniority effect: the number of dominant word types increases almost thrice when the youngest and the oldest age groups are compared. In particular, half of the responses (tokens) of the young and middle-aged participants contain 11-17 word types, whereas in the two oldest groups the number of dominant word types is 6, and these all are BCTs: zelënyj 'green', fioletovyj 'purple', rozovyj 'pink', sinij 'dark blue', goluboj 'light blue', and koričnevyj 'brown'.

Occurrence of the 12 Russian BCTs. Nearly half of all tokens $(48 \%)$ in the data were unmodified BCTs (Fig. 7). In accord with previous findings for Russian speakers in an online experiment using the same color set (Paramei et al., 2018), fioletovyj 'purple' and rozovyj 'pink' had the highest, while belyj 'white' the lowest occurrence (as we discussed in Paramei et al. (2018), high frequencies of fioletovyj and rozovyj are partly explained by relative prevalence of the corresponding stimuli in the employed color set). Although the pattern of usage of individual BCTs is generally similar across all age groups (see Fig. 3), relative to other types of color descriptors, the frequency of occurrence of the 12 BCTs significantly increases with age: e.g., $N_{20-29}=4679$ BCT tokens $(40 \%)$ among 11,581 total responses vs. $N_{70+}=2785$ BCT tokens $(72 \%)$ among 3864 total responses $\left(\chi^{2}=35.04, p<0.001\right.$; Yate's correction).

With regard to specific BCTs, in the $70+$ group we observe decrease in relative frequency of BCTs denoting the BLUE-GREEN part of the color gamut-fioletovyj 'purple', zelënyj 'green', goluboj 'light blue', and seryj 'gray'. In contrast, participants of the two young groups used these CTs more often than respondents of the middleaged groups.

Word families of the 12 Russian BCTs: derived, modified, and compounded forms. In all age groups, the 12 BCTs are core of large word families that include derived (e.g., želtovatyj 'yellowish'), diminutives (e.g., sinen'kij 'endearing sinij'), modified (e.g., jarkij oranževyj 'endearing sinij') and compounded forms (e.g., belo-goluboj 'white-goluboj') (Fig. 8). Among achromatic modifiers, the highest frequency is observed for Russian counterparts of 'dark' and 'light' (e.g., tëmno-sinij 'dark sinij' or svetlo-zelënyj 'light green'). Notably, respondents under 30 years use modifiers tëmnyj 'dark' and blednyj 'pale' much more often than participants of all other age cohorts. The inventory of achromatic modifiers becomes more meager in speakers aged 60 and older (see Fig. S1 of the Supplementary Material). Moreover, in the 70+ group it is almost completely reduced to four main ones: tëmnyj 'dark', svetlyj 'light', jarkij 'bright', and blednyj 'pale'; other achromatic modifiers, that are also emotionally laden and/or aestheticizing qualifiers-Russian for 'dirty', 'tender', 'saturated', 'deep', 'dull', and 'pastel'-occur in this group either very rarely or not at all.

Comparison of occurrences of multiword descriptors containing the BCTs in different age groups (Fig. 8) shows that, in tendency, BCT derivation, modifying and compounding is less prevalent in the two oldest groups of speakers, whereas in the young and middle-aged groups such color-naming pattern is frequently used with 'green', 'purple', and 'pink'.

Intergenerational differences in color-naming patterns: number of words in color descriptors. In the elicited color descriptors, the proportion of the BCTs markedly increases with participants' seniority (Fig. 9), with respondents of the two oldest groups offering many more BCTs (69\% and $72 \%$, respectively) than respondents of the younger age groups (40-51\%). Conversely, percentage of monolexemic non-BCTs and multicomponent word types reduces with age (Fig. 9), in accord with lower diversity indices shown in Figs. 4 and 5. In particular, older respondents offered nearly $10 \%$ less monolexemic non-BCTs (e.g., sirenevyj 'lilac' or bolotnyj 'marsh'), and a rather small fraction of multiword compounds (e.g., belo-rozovyj 'white-pink'), or CTs with achromatic modifiers denoting lightness ('light', 'dark', 'bright') or saturation ('pale', 'dull', 'tender', 'dirty') (see Fig. S1 in Supplementary Materials).

Age differences in frequent Russian non-BCTs. As is obviated by Table 3, for all Russian respondents, regardless of the age group the lists of most frequent color names $(N=30)$ include nine recurring non-BCTs-sirenevyj 'lilac', birûzovyj 'turquoise', salatovyj 'lettuce-colored', bordovyj 'claret', malinovyj 'raspberry', lilovyj 'mauve', fuksiâ 'fuchsia', beževyj 'beige', and persikovyj 'peach', whereby in their ranking the first three "overtake" the BCTs in almost all cases.

In addition, for each age group we scrutinized non-BCT types by leaning upon the classification of "novel, creative" vs. "conventional" non-basic color metonyms put forward by Casson (1994) and the classification further elaborated by 


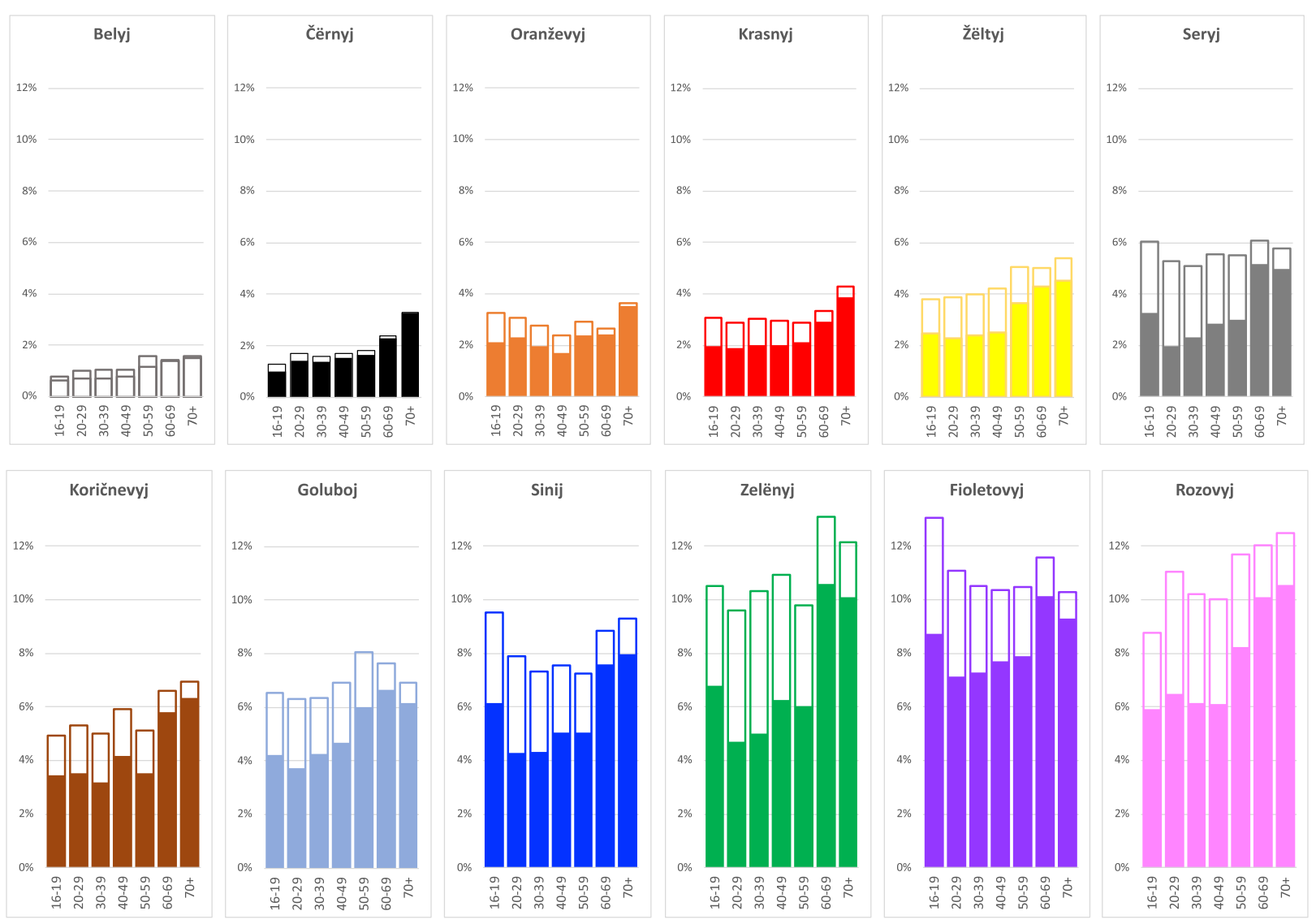

Fig. 8 Percentage of occurrences of the 12 Russian BCTs (dark shades) along with their modified and compounded forms (light shades) in color names of participants of the seven age groups. The BCTs are ordered according to the frequency of responses, from lowest (left) to highest (right).

Biggam (2012)—of "logical", "evocative", and "obscure" CTs. In our analysis, we labeled the elicited non-BCTs as "logical", "evocative", "obscure", and "conventional". As illustrated by Fig. 10, we observe significant variation in the prevalence of the four non-BCT categories in speakers of different age groups. The youngest respondents (16-19) and the mature speakers (over 60 years), i.e., at the age-scale poles, mostly use "logical" non-BCTs (e.g., limonnyj 'lemon-colored' or brusničnyj 'cowberry-colored'); they also frequently resorted to "conventional" non-BCTs (e.g., beževyj 'beige' or alyj 'scarlet') that are unambiguous in their denotative meaning for Russian speakers, although they do not have direct object-related origin. In comparison, speakers aged between 20-60 years offered more frequently "evocative" non-BCTs - through associations with objects having a certain (diagnostic) color, but without naming those objects, e.g., more na zakate 'sea at dusk'.

Further, among color descriptors of Gen Z (16-25 years old) and Millennials (26-40 years old) we identified a greater proportion of "obscure" terms that either do not name a color as such or imply a number of possible color meanings, as illustrated by an example from our dataset: Masdar 'Masdar' does not denote any particular color but is acceptable as part of a gamut of natural colors employed in eco-architecture of an Arabian sustainable city. Denotative meaning is concealed even more when in the CT guise, abstract concept terms are used (e.g., depressiâ 'depression' or mâgkost' 'softness').

Object-derived color terms. Of all responses in the dataset, 18,300 (33\%) tokens contained object-derived color descriptors (nonBCTs); these were subsumed under 2297 (7\%) color word types. Conversely, among the total number of color word types, the proportion of object-derived word types constituted $73 \%$, i.e., much higher than $49 \%$ reported by us previously for Russian respondents predominantly in their 20s (Griber et al., 2018a).

We analyzed the inventory of object referents for individual age groups: Fig. 11 shows relative number (\%) of responses containing object-derived color descriptors (tokens) and object-derived word types. It is apparent that the proportion of such terms is higher in the young and middle-aged groups, with the variety of word types highest in the youngest group (16-19).

In absolute numbers, for total respondent sample the list included 413 object referents of CTs. However, for individual age groups the number of object referents varied significantly, as depicted by the orange line in Fig. 11-from (maximal) 258 for the 20-29 year old to much lower numbers, 92 and 77, in the inventories of 16-19 and 70+, respectively (see also Table S1 in Supplementary Materials).

In our scrutiny, we focused on 30 categories of objects functioning as CT referents and grouped these into the following six classes that are justified semantically and well-defined in different European languages (cf. Grassmann and D'Achille, 2019; Griber et al., 2018a; Kerttula, 2002; Rakhilina, 2000/2008, 2007a, 2007b):

1. Flora: plants, flowers, fruits, vegetables, berries, nuts;

2. Fauna: mammals, birds, amphibians and reptilians, fish, invertebrates;

3. Inanimate nature: natural substances, natural objects, milieu, precious and semiprecious stones, chemical elements and compounds, metals;

4. Food and beverages: sweets and pastries, spices, dairy products, alcohol, hot and soft drinks; 

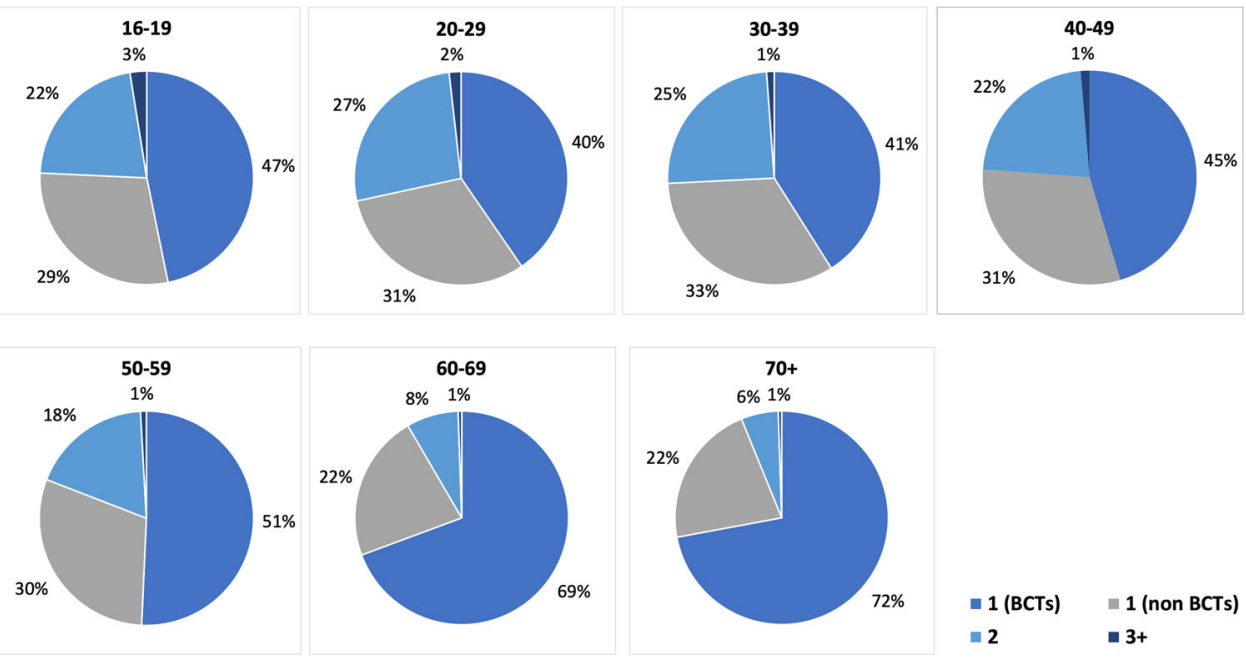

Fig. 9 Color word types with varying number of words. Percentage of the BCTs, monolexemic non-BCTs and multi-component word types in different age groups.
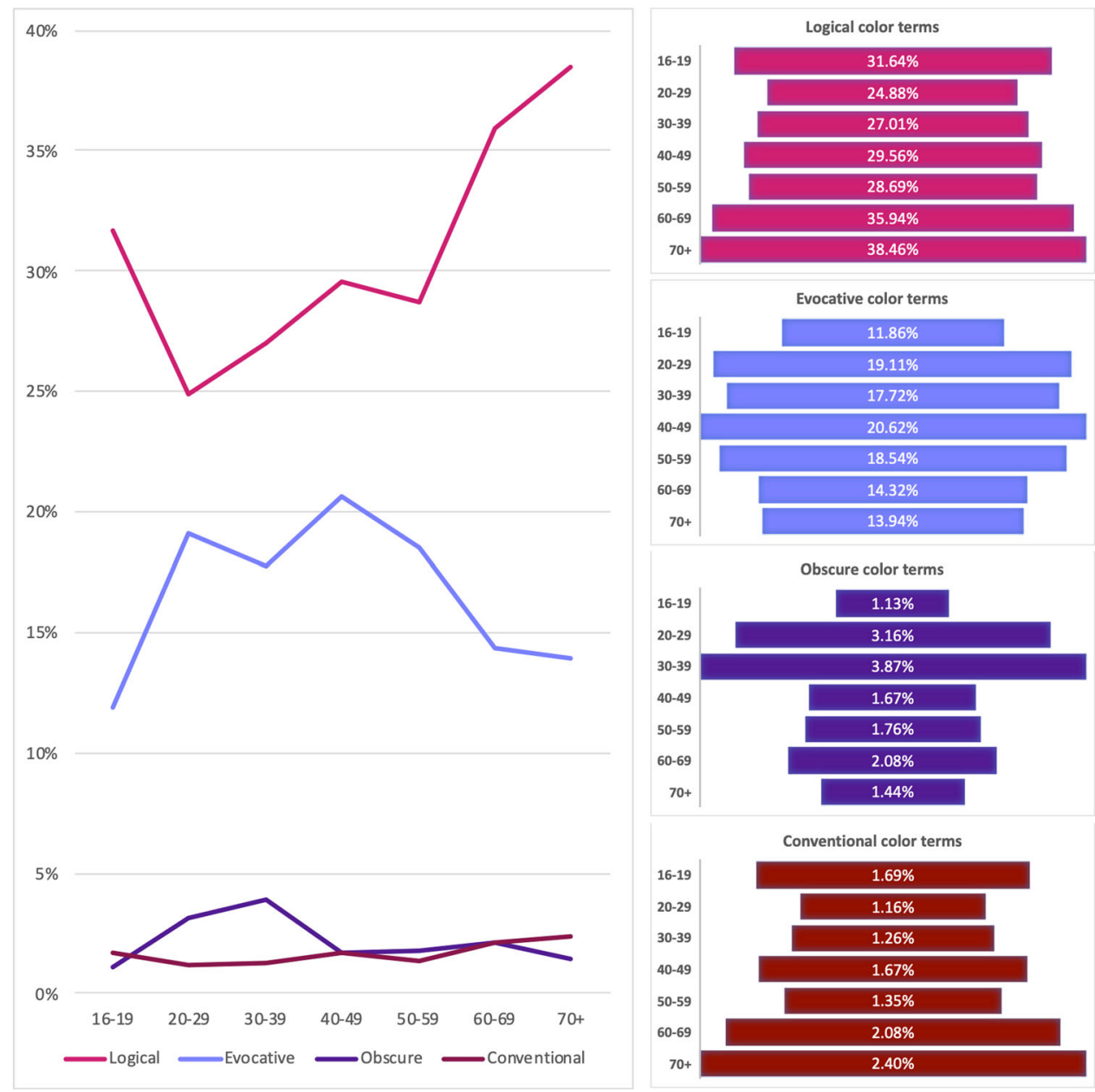

Fig. 10 Frequent Russian non-BCTs. Percentage of "logical", "evocative", "obscure" and "conventional" color terms in different age groups.

5. Man-made objects: dyes and pigments, building materials, artifacts, fabrics, cosmetics, advertisement referents;

6. Body and bodily products.

The refined division of the classes into categories, full list of object referents and their occurrences in individual age groups are presented in Table S1 (Supplementary Materials). We found that across all age groups, CT referents to Flora and Inanimate nature were among the most common object classes, followed by Manmade objects, and Food and beverages (Fig. 12 and Table S1 in Supplementary Materials). Within the referent classes, occurrences of certain categories varied between the age groups, too. Specifically, for the respondents under 30 years, the most 
common object category was Dyes and pigments (e.g., CTs derived from ocher, azure, ultramarine, indigo, ink, sienna, umber). In comparison, respondents between 30-60 years referred most frequently to the Natural substances category (such as ash, clay, dust, sand, snow, stone, water). Still different in their preferred referent choices were mature respondents: the 60-69 year old eagerly used CTs derived from the names of Plants (e.g., birch, rye, mint, grass, foliage), while the $70+$ group frequently referred to Flowers (such as lilac, cornflower, mimosa, fuchsia, pansy) and the class of Body and bodily products (flesh, blood, skin, tan, diarrhea).

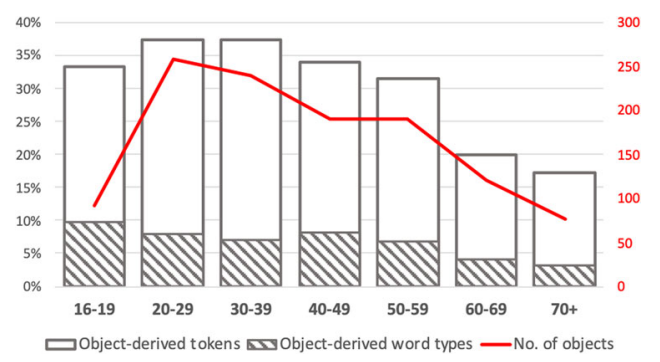

Fig. 11 Object-derived color terms. Percentage (left axis) of occurrences of object-derived color descriptors (tokens); percentage of occurrences of unique object-derived color words (word types) (superimposed, thatched), and absolute number of referent objects (right axis) in different age groups of Russian speakers.

\section{Novel ways of naming color in modern Russian}

Novel CT object referents. Along with denominal adjectives alluding to traditional Russian referents (e.g., slivovyj 'plum', malaxitovyj 'malachite'), the dataset contains abundant denominal adjectives, with a Russian suffix and ending, whose referents are newcomer objects in Russian everyday life (e.g., fuksievyj 'fuchsia', džinsovyj 'jeans-colored'). Also frequent are adjectives adopted from adjectival loanwords by attaching a Russian suffix and ending (e.g., lajmovyj 'lime', nûdovyj 'nude').

Not infrequently Russian respondents also offered terms using the pattern "cveta $X$ " 'color of X' referring to colored objects widely present in Russians' environment (e.g., cveta baklažan 'color of eggplant'). The "color of X" terms emerge before they enter the language as proper denominal adjectives (cf. Grassmann and D'Achille, 2019; Kerttula, 2002; Rakhilina, 2007a, 2007b; Rakhilina and Paramei, 2011). In the present study the occurrence of such terms is relatively high in the two youngest groups; it decreases markedly in the middle-age groups and, again, increases for respondents of 60 years and over (Fig. 13).

The mature participants used the pattern 'color of $\mathrm{X}$ ' denoting, e.g., color of clay, sky, asphalt, cornflower, skin, blood, cucumber, blueberries. In the young and middle-aged groups, the list of colored objects was more extensive and, in comparison with the older groups' natural referents, predominantly indicated as " $\mathrm{X}$ " various man-made objects-fabrics ('khaki fabric'; 'military uniform'), cosmetics ('powder'; 'lipstick'), artefacts ('traffic lights', 'felt-tip pen'); food and beverages ('milk chocolate', 'Plombir ice cream').



Fig. 12 Classes and categories of objects functioning as color-term referents. Occurrences in color naming by the seven age groups. 


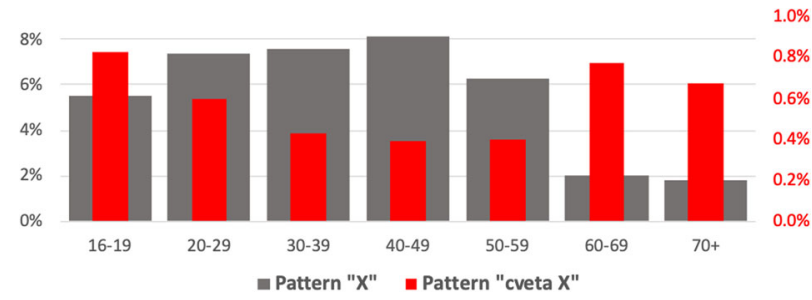

Fig. 13 Frequency of occurrences (\%) of color descriptors with the pattern "cveta X" 'color of X' (left axis) and "X" (noun-clad adjectives) (right axis) for participants of the seven age groups. Note the difference in the left and right axis scales.

Noun-clad adjectives. For Russian young and middle-aged respondents, we also observe a new grammar phenomenon in color naming: along with the traditional object-derived adjectival forms (e.g., kirpičnyj' brick-colored') or the pattern "cveta X", we record instances, although infrequent, of the object-noun pattern, i.e., pattern " $X$ ", or noun-clad adjectives (Fig. 13). The frequency of the pattern " $X$ " is highest in the 40-49 cohort; virtually it is absent in color lexicon of respondents in the two oldest groups. As "X", traditional Russian colored objects are named (e.g., baklažan 'eggplant', granat 'pomegranate', gor'kij šokolad 'bitter chocolate', čërnâ̂ maslina 'black olive"). However, some "X" object names apparently emerged as CTs only recently (e.g., čirok 'teal', cikorij 'chicory').

Loanword calques and "curtailed" Russian adjectives. Across all age groups we record a surge of transliterated calques of loanwords from other languages, mostly from English, i.e., color terms without traditional Russian adjectival suffixes and endings, such as akva 'aqua', burgundi 'burgundy', kapučino 'cappuccino', navi 'navy', šartrëz 'chartreuse', taup 'taupe', tiffani 'tiffany', etc. Also observed are transliterated names for certain pastel shades of the Pantone color catalog (e.g., sereneti 'serenity', briz 'breeze'). Furthermore, among the youngest respondents' names we find several "curtailed" traditional Russian CTs. As adjectival forms of the "parent" loanwords, most of these have been adopted in Russian in the seventeenth or eighteenth century (e.g., oranževyj 'orange'; bordovyj 'claret' ( Bordeaux); beževyj 'beige'; akvamarinovyj 'aquamarine') (Bakhilina, 1975; Vasmer, 1953). Having lost their suffixes and endings, their respective elicited forms became oranž, bordo, bež, akvamarin.

\section{Discussion}

Color inventory in Russian: cross-generational commonalities. Color names elicited from Russian respondents of several generations anew provided compelling evidence of Russians' very rich, nuanced, structurally complex, and expressive color lexicon (Astakhova, 2014; Bakhilina, 1975; Kul'pina, 2001, 2007, 2019; Moss et al., 1990; Rakhilina, 2007a, 2007b; Safuanova and Korzh, 2007; Stefanov, 2015; Vasilevich et al., 2005). The results also confirmed that, like in other languages, in Russian the structure of color-naming system has explicit linguistic nucleus and periphery. The nucleus includes the 12 BCTs (e.g., belyj 'white', krasnyj 'red', žëltyj 'yellow', etc.), including two BCTs for 'blue' - sinij 'dark blue' and goluboj 'light blue' (Davies and Corbett, 1994; Paramei, 2005), and traditional highly frequent non-BCTs (e.g., beževyj 'beige', kremovyj 'cream-colored', kaštanovyj 'maroon'). The periphery is comprised by less frequent color terms, predominantly metonymies of various objects, or prototypical referents, that are part of Russian psychological reality (e.g., slivovyj 'plum', morkovnyj 'carrot-colored') (cf. Wierzbicka, 1990).

As is apparent from Table 3 presenting list of the 30 most frequent terms across all age groups, three non-BCTs, sirenevyj 'lilac', salatovyj 'lettuce-colored', and birûzovyj 'turquoise', in their ranking compete with some BCTs and likely are on the ascent to a basic status in Russian. They also prompt that across all age groups dynamic lexical refinement occurs at the BLUEGREEN category boundary, as well as in GREEN and PURPLE categories: Table 3 attests several high-frequent non-BCTs in GREEN category-apart from salatovyj, also bolotnyj 'marsh', gorčičnyj 'mustard', khaki,_and in PURPLE category, apart from sirenevyj, recurring hyponyms malinovyj 'raspberry', lilovyj 'mauve', bordovyj 'claret', and fuksiâ 'fuchsia'. Russian speakers frequently resort to naming color by various other object-derived terms, whose referents are part of Russian psychological reality (cf. Wierzbicka, 1990), i.e., natural prototypes or socio-ethnically specific artefacts (Figs. 11 and 12 in "Age differences in frequent Russian non-BCTs"; Table S1 in Supplementary Materials; see also Griber et al., 2018a, 2020). These terms are either monolexemic adjectives (e.g., persikovyj 'peach', malaxitovyj 'malachite') or take the form "color of X" (e.g., cvet morskoj volny 'color of sea wave', cvet zelënki 'color of the brilliant green/ viride nitens tincture').

Furthermore, multiple modified and compounded forms of the 12 BCTs and frequent monolexemic non-BCTs are used (Fig. 8 in "Word families of the 12 Russian BCTs: derived, modified and compounded forms"). The former predominantly are various lightness-modified terms (see Fig S1 in Supplementary Materials). Notably, for speakers of all age groups among the 30 most frequent terms is tëmno-sinij 'dark sinij/navy blue' (Table 3) - "part of the ethnically significant color-name triad goluboj-sinij-tëmno-sinij” (Kul'pina, 2019, p. 102). Also, other lightness-modified terms are among the most frequent: tëmno-zelënyj 'dark green', svetlo-zelënyj 'light green', and tëmno-fioletovyj 'dark purple' and svetlo-fioletovyj 'light purple', which confirm the speakers' communicative necessity of linguistic nuancing of GREEN and PURPLE categories.

Finally, the modern Russian coloristic worldview is characterized by development and entrenchment of complex, multiword color descriptors (cf. Fig. 9), such as tëmno-oranževaja okhra 'dark orange ochre'. Kul'pina $(2007,2019)$ argues that this phenomenon reflects the modern Russian speakers' pursuit of color differentiation and, hence, conveyance of nuanced color shades. In addition, some complex color names, in addition to communicating the denotative meaning of a color, are emotionally laden (e.g., grâznyj konfetnorozovyj 'dirty candy pink'), esthetically charged, poetic (e.g., blednozelënyj cvet svežesrezannyx list'ev 'pale green color of freshly cut leaves'), i.e., have an expressive function, or serve as axiological markers triggering an imagination of a "dream life" (e.g., cvet lis'ej šersti $v$ knigax 'fox hair in books').

Processes and factors implicated in intergenerational differences in color vocabulary. Recent research on language across the lifespan demonstrated that semantic and lexical knowledge accumulates during adulthood and remains stable until very old age (see e.g., Burke and Shafto, 2008). Our results, too, indicate that color vocabulary develops actively throughout the entire adult life and remains relatively stable in richness and diversity up to the age of 60 years (Figs. 3-5). Along with the characteristics of Russian color naming that are common to speakers of all studied age groups, the present apparent-time analysis revealed significant differences in generational color idiolects of Russians-, namely. variation in frequency of certain color terms, their modifiers and compounds, object referents, patterns of color descriptors, as well as communicative functions inherent in naming colors. The differences in age cohorts' color lexicons reflect intertwined general processes and Russian-specific factors that we summarize briefly. 


\section{General:}

socio-cognitive factors: as pointed out by Vejdemo (2017, p. 144), "[t]he similarities in the language pattern of an age group could then both be a result of similar childhood experiences, leading to a fossilization of a large part of language by the time they are adults, and also due to similar experiences later in life". In the Russian-specific context it is worth adding that age cohorts' differences in life experiences are shaped by unique historical events unfolding during their lifetimes and specific cultural contexts in which they live (cf. Pichler et al., 2018; Wulff et al., 2019);

sociolinguistic factors: according to the incrementation model (Labov, 1990, 2001), apparent-time analysis unveils incipient changes, small but consistent shifts in speakers' lexicon. In particular, this manifests as the juniority effect of lexical expansion, whereby younger speakers demonstrate a richer lexicon and more diversified vocabulary (Tagliamonte and D'Arcy, 2009);

changes in color perception caused by normal aging of the visuals system manifesting by poorer discrimination of colors in general (Barbur and Rodriguez-Carmona, 2015; Paramei and Oakley, 2014; Pérez-Carpinell et al., 2006; Wuerger, 2013) and of desaturated and washed-out colors, in particular (Hagerstrom-Portnoy et al., 1999);

normal aging of cognitive functioning, among other, has an impact on language processing (e.g., Brysbaert et al., 2016; Burke and Shafto, 2004, 2008; Clark-Cotton et al., 2007; Connor et al., 2004; Thornton and Light, 2006).

Russian-specific are dramatic political and socio-economic changes post-1991, when the socialist system was replaced by the capitalist economic system; as part of these, Russia's markets were opened for massive influx of western products. Inevitably, the tectonic social changes were reflected in the language of Russian speakers immersed in the new reality. In particular, these processes included of the visual environment containing novel man-made objects, which ensued the need to communicate about novel object colors and dyes (cf. Zaslavsky et al., 2020). As pointed out by Lindsey and Brown (2019:p. 127), "changes in the pragmatic utility of color terminology within a culture, under the pressure of advancing technology, [are] a crucial factor governing increases in color lexicon complexity". We posit that the impact on Russian respondents' language was greatest for our four younger age groups ranging from 16-49 years, or Gen Z, Millennials and Generation X (Strauss and Howe, 1991, 2000). Their cognitive and social functioning was developing and/or crystalizing in the reality founded on traditional Russian natural and cultural environment but dominated by globalized marketing, commerce, and digital-world communication.

Below we discuss outcomes of apparent-time analysis in color vocabulary and color-naming patterns of Russian speakers, as well as assumed mechanisms underlying intergenerational differences; we address these in the descending age-group order.

Mature speakers (60-69 and 70+ age groups). In the mature Russian speakers, we observe decline in both richness and diversity of color lexicon (Figs. 4 and 5), in accord with general findings for vocabulary size and lexical diversity (Brysbaert et al., 2016). Compared to other age cohorts, their color inventory is dominated by the BCTs (Fig. 9); reveals lower number of word types and BCT-derivatives (Fig. 3), lexical reduction of usage and scope of non-BCTs (Fig. 9, Table S1 in Supplementary Materials). Behind the negative color-naming dynamics with advancing age probably is accelerating decline of naming performance in general (Connor et al., 2004). Mature speakers experience difficulty retrieving a specific word, although they might know more words than young adults (see e.g., Burke et al., 2000; Kemper, 2006; Kemper and Sumner, 2001; Thornton and Light, 2006). Our data are also in accord with the findings that the decline ebbs away most rapidly after the age of 70 years (Lindenberger and Baltes, 1997), as illustrated by Figs. 1, 4 and, in particular, by Fig. 6 showing that the $70+$ group forms a cluster separated from that for 60-69 year old.

Among non-BCTs offered by the two mature groups predominant are "logical" and "conventional" terms (see Fig. 10) that are transparent with regard to the color of the object referent and unambiguous in their denotative meaning, thus, mainly having the information function (cf. Kul'pina, 2019). We note that one of the new terms, fuksia 'fuchsia', is on the list of the most frequent color names also for these two age groups (Table 3). Otherwise, the mature Russian speakers practically do not use "fancy" or "marketing" color names that are becoming increasingly profuse in Russian due to fashion and advertising, but resort to non-BCTs that are traditional, culturally embedded, predominantly with natural, Flora, referents (see Fig. 12).

Comparative analysis of color-term inventories in different age cohorts demonstrates that low-frequency color descriptors disappear primarily from color lexicon of the "young-old" and "medium-old" speakers. This finding is in line with a longstanding hypothesis that, in general, memory traces are subject to passive, gradual decay as a result of not using the particular trace (Hardt et al., 2013; Niv et al., 2015). The observed tendency is also in accord with the findings related to aging effects in general vocabulary: frequent use of high-frequency words maintains the strong connections in their representations aiding their retrieval; conversely, connections for low-frequency words weaken from disuse and, in the case of extreme disuse, disappear from the lexicon (James and MacKay, 2001).

Further, we observe that in denoting color, the mature respondents are rather conservative: they rarely used multiword expressions (see Fig. 9) prefer traditional Russian language adjectival forms instead of the object "parent" noun, which is the novel linguistic phenomenon, apparently, resulting from trading globalization and under the influence of the word-formation pattern in English (modern lingua franca) (cf. Griber et al., 2018a).

The conservative non-BCT vocabulary of the mature Russian speakers conceivably is related to the known cognitive changes with aging, specifically, more solidified mental representations of object concepts (cf. Schmid, 2017), and decline of formation of new semantic representations (e.g., McIntyre and Craik, 1987; Schacter et al., 1994), resulting from deterioration of the ability to learn new associations (Naveh-Benjamin and Kilb, 2014). Apart from the aging-related semantic changes, the observed tapering of the color-term inventory may also reflect a motivational changea shift in old age from the goal of accumulating knowledge to goals that bring immediate satisfaction because of the uncertainty of the future when this knowledge would be put to use (e.g., Carstensen, Isaacowitz, and Charles, 1999).

Along with the cognitive aspects, the observed changes in color naming in the two mature-age cohorts may reflect perceptual aging effects. In particular, relatively frequent use of BCTs from 60 years onwards may be related to the lifespan 'knee' (Hagerstrom-Portnoy et al., 1999; Paramei and Oakley, 2014) in the ability to discriminate hue shades (within basic color categories). The overall "darkening" of perceived colors with age (Knoblauch et al., 1987) probably explains noticeable decrease in using 'red', 'orange' and goluboj 'light blue' terms (see Fig. 7): the "middle-old" (75-84 years) and "oldest-old" individuals (aged 
85 years and over) may perceive-and name-red, yellow or orange colors as 'brown' (cf. Hassan et al., 2018). The dwindling use of lightness-modifiers (see Fig. S1) may, too, reflect poorer discrimination of desaturated and washed-out colors caused by the aging processes in the visual system (Hagerstrom-Portnoy et al., 1999).

Middle-aged speakers (40-49 and 50-59 groups). According to our analysis, Russian speakers the two middle-aged groups, in their $40 \mathrm{~s}$ and $50 \mathrm{~s}$, i.e., born between 1958-1979, are similar in color lexicon (see Fig. 6). This relates to richness and diversity of their color inventory (Figs. 3-5); percentage of occurrence of the 12 Russian BCTs (Fig. 7), and BCT modified and compounded forms (Fig. 8); color-naming pattern (Figs. 9 and 11); variety of lightness-modifiers (Fig. S1); as well as the scope of Flora referents of non-BCT (Fig. 12). Color inventory of these two age groups, although higher on all listed parameters, in its pattern (variety of color descriptors, color word types, objects referents, etc.) is similar to that of Russian speakers in their 60s (Fig. 6). We attribute this similarity to the fact that all three are age cohorts, whose semantic systems developed and stabilized before 1991, i.e., during a historical period of socio-economic and political isolation of the Soviet Union and of relative stagnation, when Russian's psychological, ethno-cultural reality-perceptual, conceptual, and axiological-was greatly homogeneous and hardly changing during several decades. In this framework, the Russian aged 40-69 share a common "coloristic conceptual sphere" (Kul'pina, 2019), being part of their similarly molded ethnolinguistic mind.

We also observe, however, several differences, too. First, Table 3 obviates that the three most frequent non-BCTs addressed in "Color inventory in Russian: Cross-generational commonalities", sirenevyj 'lilac', birûzovyj 'turquoise', and salatovyj 'lettucecolored', in the middle-aged speakers' list have notably higher ranking in those of the mature speakers. Four other PURPLE hyponyms, bordovyj 'claret', malinovyj 'raspberry', lilovyj 'mauve', and fuksiâ 'fuchsia', are on the ascent too. Second, the scope of CT referents is noticeably expanded (Table S1 of Supplementary Materials): along with Flora, it includes Inanimate nature (e.g., grafit 'graphite', ajsberg 'iceberg', zelënyj briz 'green breeze', neonovyj sinij 'neon sinij') and many more Man-made objects (e.g., cvet mokrogo asfal'ta 'color of wet asphalt', sinij Klejna 'Klein blue'). Notably, the latter include novel metonymic CTs referring to artifacts (e.g., maxagon 'mahogany', rozovyj Barbi 'pink Barbie'), that the middle-aged speakers frequently encounter in their post-1991 daily life as part of the active workforce and consumers.

Finally, as suggested by Fig. 10, compared to the 60-69 group, the middle-aged speakers resort more often to "evocative" color names (e.g., more na zakate 'sea at dusk') seemingly greatly at the expense of "conventional" terms (e.g., alyj 'scarlet', bagrovyj 'crimson', bagrânyj 'purplish-red'). Leaning upon Kul'pina's (2019) classification of various communicative functions of color naming, we interpret this phenomenon as partial supplanting of informative function, which prevails in the mature speakers', in communication about color and augmenting its expressive function-aesthetization and emotional finesse of the conveyed color.

The young age groups (16-19, 20-29, and 30-39). Color inventories of Russian speakers in their 20s and 30 s (Generation Y/Millennials) - the age cohorts that grew up in the post-Soviet period-are rather different from those of other age groups (see Fig. 6). Even more so is color lexicon of the 16-19-year-old (Gen $\mathrm{Z}$ ), who started their education and reached adulthood in the first decade of the twenty-first century. All three age groups reveal high diversity, and rich and variegated color vocabulary (Figs. 3-5). Along with the 12 BCTs, they frequently use non-basic terms (Table 3), and modified or compounded BCTs (Fig. 8). As in the middle-aged speakers' list, the three high-ranking nonBCTs sirenevyj, birûzovyj and salatovyj are in the usage ascendant in younger speakers "overtaking" some BCTs. Other hyponyms in PURPLE and GREEN category rise in ranking, too. In addition, we observe incipient lexicalization of the "difficult-to-name" color space areas: the terms denoting these are rank-rising (beževyj 'beige', persikovyj 'peach') or entering the list of most frequent color names (okhra 'ocher').

More than other age cohorts, the younger speakers also offer a greater proportion of object-derived terms and the corresponding word types (see Fig. 11). Notably, the choice of referents has significantly shifted (see Fig. 12, Table S1) to the Man-made objects, especially, Artefacts and Dyes and pigments categories, and Food and beverages, in particular, the categories of Sweets and pastries and Dairy products. Abundant among novel color terms in these three age groups are loanwords (mostly from English) that are either calques (e.g., tiffani 'tiffany', taup 'taupe') or adopted in Russian as adjectival forms by attaching a suffix and ending (šagrenevyj 'chagrin', pûsovyj 'puce'). There are also dynamic changes in color-naming pattern: as prompted by Fig. 9, younger Russian speakers tend to name colors more frequently than other age cohorts by using multiword expressions. A scrutiny reveals that these descriptors are predominantly "evocative" color terms. Further, among younger respondents' names we observe a surge of "obscure" terms, nonce-formations, or terms that convey idiosyncratic experiences, rather than denotative meaning of the perceived color (e.g., moj lubimyj cvet 'my favorite color'; staroje odeâlo 'old blanket'): while being comprehensible for the respondent, the allusion eludes others. Note also that not infrequently such adjectives are clad as nouns denoting the referent object.

Concluding remarks: the apparent-time analysis reveals dynamism in Russian color-naming. We summarize the colorinventory dynamism revealed by the apparent-time analysis. We focus, in particular, on juniority effects in Russian color naming by younger and middle-aged cohorts that include Gen Z, Millennials, and Generation X. In general, these effects manifest an expected replenishment of color lexicon. Importantly, beyond this, we observe Russian-specific juniority effects stipulated by dramatic political and socio-economic changes in post-1991 that enrolled the Russian society in the orbit of global trade and marketing, which ensued extraordinary cultural and, hence, ethnolinguistic transformations. Specifically, young generations' color vocabulary is characterized by substantial enriching by novel object referents and loanwords; innovation of the grammar form (noun-clad adjectives); elaboration and refinement of colornaming patterns; and, along with informative and cognitive functions of denoting color shades, an increasing tendency of expressive function, and anesthetization and axiological potential in naming color.

Below we highlight some observed apparent-time phenomena that are specific to Russian color-naming development and, also, have parallels in real-time developments of color inventories in other languages.

Emerging basic color terms. We single out the three highly frequent non-BCTs sirenevyj 'lilac', birûzovyj 'turquoise', and salatovyj 'lettuce-colored' that in their ranking compete with some Russian BCTs, are evident ascendants in the young speakers' lexicon (see Table 3). 
In particular, sirenevyj, while ranking $12(70+)$ and 10 (60-69), gained rank 6-8 in speakers under 60 years of age. This change is comparable to the real-time development during ca. 20 years, if one compares its rank 13 (Davies and Corbett, 1994; age range 18-65 years) vs. rank 8 (Paramei et al., 2018; 16 years and over).

Slightly behind it but on the same trajectory is birûzovyj steadily ascending in its rank in the younger generations, from rank $17(70+)$ and $14(60-69)$ to rank 10 in respondents aged 16-39 years. Again, this development is comparable to the realtime change of the term usage: rank 19 (Davies and Corbett, 1994) vs. rank 9 (Paramei et al., 2018).

In comparison, salatovyj is relatively stable in usage of speakers of different age groups, with ranking drifting between 11-15 (see Table 3), however, the real-time change of the term usage is apparent, too: from rank 23 (Davies and Corbett, 1994) it ascended to rank 14 (Paramei et al., 2018).

We remark that Mylonas and MacDonald (2016) demonstrated that lilac and turquoise, British English (BE) counterparts of sirenevyj and birûzovyj, meet several criteria of basicness (frequency and consistency of usage, response times, and denotative volume); the authors posit that these two terms augment the BE color inventory of BCTs to 13. In a similar vein, in the American English (AE) color lexicon, Lindsey and Brown (2014) identified lavender, similar to BE lilac, and teal, $\mathrm{AE}$ counterpart of BE turquoise, among several candidates of nonbasic color terms to join the AE BCT inventory. We assume that sirenevyj and birûzovyj are, too, emerging as basic in Russian, though a stringent assessment of their status would require a separate study. The converging evidence from the three languages calls for a closer look at the color space areas where novel BCCs emerge, across languages, investigating driving forces of this process, and revisiting the notion of the 11 BCT ceiling in color inventory (cf. Paramei and Bimler, 2021).

Linguistic refinement of certain color categories. We notice intergenerational differences in frequency of usage of non-BCTs at the RED-PURPLE category boundary and those denoting shades of PURPLE (see Table 3), the category historically highly lexically refined in Russian (Davies and Corbett, 1994; Moss, 1988). Noticeably, the traditional Russian non-basic bordovyj 'claret', malinovyj 'raspberry', and lilovyj 'mauve' are complemented by relatively novel fuksiâ 'fuchsia' (cf. Paramei et al., 2018); its rank is higher in the young(er) groups of speakers compared to the middle-aged and mature ones. Similarly, lexical refinement of PURPLE was reported for AE-fuchsia, mauve (Lindsey andand Brown, 2014), for BE-mauve, fuchsia, violet, plum (Mylonas and MacDonald, 2016), and Polish-bordowy 'claret', fiołkowy 'violetcolored, lilac', liliowy 'mauve' (Kul'pina, 2019).

We also observe further lexical refinement of GREEN category: as the list in Table 3 prompts, frequent are object-derived hyponyms at its "brownish" periphery- bolotnyj 'marsh', khaki, and gorčičnyj 'mustard', as well as lightness-modified terms 'light green' and 'dark green'. Again, this echoes the ongoing category lexical partitioning by lime, olive, mustard in AE (Lindsey and Brown, 2014) by olive, in BE (Mylonas and MacDonald, 2016).

Other frequent Russian non-BCTs that recur across all generations and are relatively stable in ranking are beževyj 'beige' and persikovyj 'peach'; in the youngest group's list a new frequent addition is okhra 'ocher' (see Table 3). Noteworthy, these terms lexicalize the "no-man's area" in color space straddling the boundaries between YELLOW, PINK, ORANGE, and BROWN categories. In these instances, we too find parallels in other languages, whose real-time changes in color inventories were explored in recent years (Paramei, 2020). In AE, the counterparts are beige, flesh, peach (Lindsey and Brown, 2014), in BE peach, beige, ocker (Mylonas and MacDonald, 2016), and in Japanese hada 'skin', oudo 'sand/mud', beige (Kuriki et al., 2017).

Intergenerational shifts in color-term referents. Scrutiny of the object-derived color terms in different age groups (Fig. 12, Table S1) makes inescapable an intergenerational shift in color referents as "semantic anchors": while middle-aged and older groups predominantly use natural objects, the younger speakers refer more often to man-made objects. Importantly, in the vocabulary of the middle-aged and young respondents (16-59)-active consumers-the gamut of metonymic color terms expanded exceptionally due to substantial influx of western products to the Russian market post-1991-artefacts, dyes and pigments (e.g., magenta), "foreign" flowers (e.g., amaranth, sakura) and animals (taup), building materials (e.g., wenge wood), and food products (e.g., marshmallow). Some terms (we counted 39 in total) apparently emerged very recently (e.g., navi 'navy', zelënyj čaj 'green tee'), since they have not been attested in the catalog published less than two decades ago (Kharchenko, 2009; Vasilevich et al., 2005). The youngest respondents more than other age cohorts use "non-native" referents of " $\mathrm{X}$ " (e.g., indigo, ivory).

As in other languages (e.g., Smith, 2000), fashion, fast changing trade, and clothing catalogs, advertisements of cosmetics, house painting etc. extensively feed into the innovation of object referents in modern Russian, in particular, by creating "fancy" color terms (e.g., Gorlacheva, 2009; Nasibullina, 2010; Romanik, 2019; Sun and Charykova, 2016; Vasilevich, 2004). In our list we find fashion-inspired novel coloratives such as tiffani 'tiffany', tango 'tango', or niagara 'Niagara'.

If one considers the inventory of Russian "edible" color terms, with food products, beverages, spices, fruit etc. as referents (Griber et al., 2018b), we, too, observe an intergenerational shiftfrom traditional references (e.g., šokoladnyj 'chocolate', moločnyj 'milky') in the older respondents' names to many novel terms in the middle-aged and young (e.g., karri 'curry', marsala 'marsala wine'). This term innovation and expansion apparently reflect the variation of "gastronomic" reality of different age groups of Russian speakers-their characteristic cuisine, but also the array of available food products.

Russian color-naming innovations: novel grammar forms, patterns, and communicative functions. As indicated in "Noun-clad adjectives" and "Loanword calques and "curtailed" Russian adjectives", the elicited color names not infrequently take the form of noun-clad adjectives (e.g., cikorij 'chicory', tykva 'pumpkin'), loanword calques (e.g., šampan' 'champagne', lajm 'lime') and the "curtailed" form of traditional Russian adjectives stripped of suffixes and endings (e.g., bordo $\leftarrow$ bordovyj 'claret'; bež $\leftarrow$ beževyj 'beige'). The curtailed forms are not new in Russian (e.g., Kharchenko, 2009), but their proliferation in our list prompts that they became more frequent in recent times. In addition, the responses offered in this experiment, under the instruction of using any type of color name, probably reflect modern Russian vernacular, which is less conservative than written language (cf. Vejdemo, 2017): such forms are not attested in the Russian Corpus (by 2009) whose data contain literary texts. We remark that the curtailed color names are also recorded in modern Polish (Kul'pina, 2019); this hints to a linguistic phenomenon that in the world of globalized trade and active contact with English language is emerging across Slavic languages whose conventional adjectives include suffixes and endings.

Apart from referents and grammar forms, the age cohorts appear to differ in the patterns of naming color and communicative functions implied in it. In tendency, the mature and middle-aged Russian speakers name color to ensure communicative efficiency, that implicates informative function, whereas 
young speakers much more frequently use color descriptors as a means of "self-expression", i.e., pursue the expressive function.

In particular, the mature speakers over 60 years, but also the youngest respondents (16-19) (see Fig. 10) manifest a conservative strategy of color naming, mostly using "logical" nonBCTs implying metonymy and "transparent" with regard to the color of the object referent (e.g., limonnyj 'lemon-colored' or brusničnyj 'cowberry-colored'). Speakers of these three age-scale poles also frequently resorted to "conventional" non-BCTs (e.g., beževyj 'beige' or alyj 'scarlet') that are unambiguous in their denotative meaning for Russian speakers.

In comparison, Russian speakers aged between 20 and 60 years are also imaginative in frequently offering "evocative" non-BCTs (Fig. 10) - through associations with well-known artefacts that have a diagnostic color, but without naming the color per se (e.g., Barbi 'Barbie'; svečenie aifona 'glow of an iPhone'). In these cases, alluding to the referents helps specifying not only the color but also its luminous or specular characteristics (matte, shine, depth, saturation etc.) that are not conveyed by "simple" color terms (cf. Griber et al., 2018a). Respondents from the two youngest groups are linguistic innovators: they resort to many unconventional (e.g., Ispaniâ 'Spain', armiâ 'army') or imaginative idiosyncratic impressions (e.g., babuškina čaška 'grandmother's cup', Nataša 'Natasha'). As pointed out by Biggam (2012, p. 49), "novel terms are invented for particular needs and circumstances, and these new coins ... are rarely found in standard dictionaries of the language concerned".

We observe that "evocative" terms often implicate "non-native" referents transliterating English loanwords (e.g., ajsberg 'iceberg', lajm 'lime', tiffani 'tiffany', taup 'taupe'). As in English, they are used solely in the "marketing" discourse in relation to premium brands, influenced by "onomasiological competition" between lexical forms in the individual product categories (cf. Anishchanka et al., 2015).

Multi-component descriptors of different age cohorts appear to serve different communicative functions, too. In particular, the older and middle-aged respondents use compounds predominantly to convey the denotative meaning of color in a greater detail. Their multiword expressions often are emotionally laden and poetic, i.e., serve the expressive function; as a rule, they contain a BCT, non-BCT or " $\mathrm{X}$ " with modifiers and qualifiers (golubaja volna 'golubaja wave'; sočnaja zelen' 'juicy greenery'), or allude to objects or nature events having a diagnostic color it (e.g., more na zakate 'sea at dusk', pasmurnoje nebo 'color of a murky sky').

In comparison, the proliferation of compounded CTs in young Russian respondents is probably mainly attributable to the fashion industry (cf. Grossmann and D'Achille, 2019). The younger generations are also imaginative in and multiword expressions that usually are "evocative" terms that imply elation, anesthetization and affective finesse. In such expressions, the "color of X" model is frequently used, where " $X$ " is a natural object referent accompanied by highly elaborate qualifiers (e.g., cvet svežesrezannyx list'ev 'color of freshly cut leaves', cvet opalënnyx uglej 'color of burnt coals', cvet koži mokroj lâguški 'the color of the skin of a wet frog', cvet osennej travy posle doždâ 'color of autumn grass after the rain', cvet utrennego snega 'color of the morning snow').

As remarked by Biggam (personal communication), "every generation likes to erect linguistic boundaries and barriers between it and the parental generation ... Some 'young' color terms may not be understood by older people or, more likely, they may be understood but not used by older people ... most members of Generation $\mathrm{Z}$ in particular would be delighted to have color terms not understood by older people. They're likely to actively invent them".
Different patterns of using in non-BCTs color naming by native speakers from different generations raises another pointthat color terms can switch between logical, evocative, and obscure for individual speakers and perhaps, too, for age groups. Biggam further suggests that It may be that the differences in color naming are "litmus paper" for manifesting intergenerational differences in mentality and implicit goal of communication, namely, to be understood by others (middle-aged and mature speakers) vs. to express personal affect by the young speakers.

We conclude by reiterating that the apparent-time analysis afresh substantiates the view of Russian color-term vocabulary as exceptionally rich and variegated. Furthermore, it provides evidence of ongoing augmenting of the inventory of basic color terms in Russian and lexical refinement by non-BCTs in certain color categories or boundaries between these. The intergenerational differences in Russian color names follow the incrementation model. In post-1991 Russia, the juniority effect of expansion and transformation of color vocabulary was accelerated by extralinguistic factors due to dramatic political and economic changes - opening of the country's market to influx of ample western products with new colors. As result of Russia joining the globalized trade, novel non-basic color terms, profuse in fashion and advertisements, were adopted from other languages, predominantly English, either to supply names for colors or shades, which had not thus far been labeled in Russian or to replace some native terms. As pointedly commented by Biggam (2012, p. 56), “ $[\mathrm{t}]$ he motivation for either process may involve more than the desire for increased precision, as the target-language speakers may be more concerned with sounding 'modern' or fashionable in cases where the source language is prestigious".

\section{Data availability}

The datasets generated and analyzed during the study currently are not publicly available as they form part of the authors' ongoing research. They can be available from the corresponding author on reasonable request.

Received: 2 February 2021; Accepted: 15 October 2021; Published online: 04 November 2021

\section{References}

Anishchanka A, Speelman D, Geeraerts D (2015) Usage-related variation in the referential range of blue in marketing context. Funct Lang 22(1):20-43. https://doi.org/10.1075/fol.22.1.02ani

Astakhova JA (2014) Cvetooboznačenija v russkoj jazykovoj kartine mira [Color terms in the Russian linguistic worldview]. Ph.D thesis, Moscow, MPGU (in Russian)

Bakhilina NB (1975) Istorija cvetooboznačenij v russkom jazyke [History of color terms in Russian]. Nauka, Moscow (in Russian)

Barbur JL (2004) 'Double-blindsight' revealed through the processing of color and luminance contrast defined motion signals. Prog Brain Res 144:243-260. https://doi.org/10.1016/S0079-6123(03)14417-2

Barbur JL, Rodriguez-Carmona M (2015) Color vision changes in normal aging. In: Elliot AJ, Fairchild MD, Franklin A (eds) Handbook of color psychology. Cambridge University Press, Cambridge, UK, pp. 180-196

Berlin B, Kay P (1969/1991) Basic color terms: their universality and evolution. University of California Press, Berkeley

Biggam CP (2012) The semantics of colour: a historical approach. Cambridge University Press, Cambridge, UK

Brysbaert M, Stevens M, Mandera P, Keuleers E (2016) How many words do we know? Practical estimates of vocabulary size dependent on word definition, the degree of language input and the participant's age. Front Psychol 7:1116. https://doi.org/10.3389/fpsyg.2016.01116

Burke DM, Shafto MA (2004) Aging and language production. Curr Dir Psychol Sci 13:21-24. https://doi.org/10.1111/j.0963-7214.2004.01301006.x 
Burke DM, Shafto MA (2008) Language and aging. In: Craik FIM, Salthouse TA (eds) The handbook of aging and cognition. Psychology Press, New York, NY, pp. 373-443

Burke DM, MacKay DG, James LE (2000) Theoretical approaches to language and aging. In: Perfect T, Maylor E (eds) Models of cognitive aging. Oxford University Press, Oxford, pp. 204-237

Carstensen LL, Isaacowitz DM, Charles ST (1999) Taking time seriously. Am Psychol 54:165-181. https://doi.org/10.1037/0003-066X.54.3.165

Casson RW (1994) Russet, rose, and raspberry: the development of English secondary color terms. J Linguist Anthropol 4:5-22. https://doi.org/10.1525/ jlin.1994.4.1.5

Clark-Cotton MR, Williams RK, Goral M, Obler LK (2007) Language and communication in aging. In: Birren JE (ed) Encyclopedia of gerontology: Age, aging, and the aged, 2nd edn. Elsevier, London, pp. 1-8

Connor LT, Spiro AIII, Obler LK, Albert ML (2004) Change in object naming ability during adulthood. J Gerontol B 59:203-209. https://doi.org/10.1093/ geronb/59.5.P203

D'Arcy A (2006) Lexical replacement and the like(s). Am Speech 81:339-357. https://doi.org/10.1215/00031283-2006-024

Davies IRL, Corbett GG (1994) The basic color terms of Russian. Linguist 32:65-89. https://doi.org/10.1515/ling.1994.32.1.65

Davies IRL, Roling P, Corbett GG, Xoagub F, Xoagub J (1997) Color terms and color term acquisition in Damara. J Linguist Anthropol 7:181-207. https:// doi.org/10.1525/jlin.1997.7.2.181

Dougherty JWD (1977) Color categorization in West Futunese: Variability and change. In:Blount BG (ed) Sociocultural dimensions of language change. Academic Press, New York, NY, pp. 143-148

Enoch JM, Werner JS, Haegerstrom-Portnoy G, Lakshminarayanan V, Rynders M (1999) Forever young: visual functions not affected or minimally affected by aging: A review. J Gerontol A-Biol 54(8):B336-B351. https://doi.org/10.1093/ gerona/54.8.B336

Fisher GG, Stachowski A, Infurna FJ, Faul JD, Grosch J, Tetrick LE (2014) Mental work demands, retirement, and longitudinal trajectories of cognitive functioning. J Occup Health Psychol 19(2):231-242. https://doi.org/10.1037/a0035724

Forbes I (2006) Age-related differences in the basic colour vocabulary of French. In: Biggam CP, Kay CJ (eds) Progress in colour studies. Language and culture, vol I. John Benjamins, Amsterdam/Philadelphia, pp. 101-109

Frumkina RM (1984) Cvet, smysl, sxodstvo. Aspekty psixolingvističeskogo analiza [Color, meaning, and similarity: Aspects of a psycholinguistic analysis]. Nauka, Moscow (in Russian)

Frumkina RM, Mikhejev AV (1996) Meaning and categorization. Nova Science, New York, NY

Gamito S (2010) Caution is needed when applying Margalef diversity index. Ecol Indic 10:550-551. https://doi.org/10.1016/j.ecolind.2009.07.006

Gorlacheva VV (2009) Gendernye osobennosti cvetooboznačenij v sovremennom russkojazyčnom reklamnom diskurse [Gender specificity of color names in modern Russian-language advertisement discourse]. Visnik Zaporizh'skogo Nacional'nogo Universitetu. Filologični Nauki 1:22-28 (in Russian)

Griber YA, Dvoinev V (2018) Obosnovanie vyborki massovogo èksperimental'nogo obsledovaniâ nositelej russkogo âzyka, napravlennogo na diagnostiku razvitiâ sistemy cretooboznačenij [Validation of a sample in a large-scale survey of native Russian speakers aimed at assessing the development of a color-naming system]. Bulleten' nauki i praktiki 4:528-536 (in Russian)

Griber YA, Mylonas D, Paramei GV (2018a) Objects as culture-specific referents of color terms in Russian. Color Res Appl 43(6):958-975. https://doi.org/ $10.1002 / \mathrm{col} .22280$

Griber YA, Mylonas D, Paramei GV (2020) "Edible" colour names: age-related differences in Russian. In: Caivano JL (ed) Proceedings of the International Color Association (AIC) Conference 2019. AIC, Newtown, NSW, pp. 256-262

Griber YA, Mylonas D, Paramei GV. Intergenerational differences in Russian color naming in the globalized era: Psycholinguistic analysis (in preparation)

Griber YA, Paramei GV (2019) The influence of professional color competence on color lexicon and naming pattern. In: Almazova NI, Rubtsova AV, Bylieva DS (eds) The European Proceedings of Social \& Behavioural Sciences, vol. 73. Future Academy, St. Petersburg, pp. 647-663

Griber YA, Paramei GV, Mylonas D (2018b) "Edible" colour names: Cross-cultural comparison of Russian and English. In: Proceedings of the International Colour Association (AIC) Conference, Lisbon, Portugal, 25th-29th September 2018. International Colour Association (AIC), Lisbon, pp. 497-502

Grossmann M, D'Achille P (2019) Compound color terms in Italian. In: Raffaelli I, Katunar D, Kerovec B (eds) Lexicalization patterns in color naming: A crosslinguistic perspective. John Benjamins, Amsterdam/Philadelphia, pp. 61-79

Hagerstrom-Portnoy G, Schneck ME, Brabyn JA (1999) Seeing into old age: Vision function beyond acuity. Optom Vis Sci 76:141-158. https://doi.org/10.1097/ 00006324-199903000-00014

Hardt O, Nader K, Nader L (2013) Decay happens: The role of active forgetting in memory. Trends Cogn Sci 17(3):111-120. https://doi.org/10.1016/ j.tics.2013.01.001
Hardy JL, Frederick CM, Kay P, Werner JS (2005) Color naming, lens aging, and grue: What the optics of the aging eye can teach us about color language. Psychol Sci 16:321-327. https://doi.org/10.1111/j.0956-7976.2005.01534.x

Hassan MF, Paramesran R, Tanaka Y, Tanaka K (2018) A method using uniform yellowing pigmentation to model the color perception of the elderly people. Signal Image Video Process 12(7):1019-1026. https://doi.org/10.1007/ s11760-018-1247-3

James LE, MacKay DG (2001) H.M., word knowledge and aging: Support for a new theory of long-term retrograde amnesia. Psychol Sci 12(6):485-492. https:// doi.org/10.1111/1467-9280.00390

Kay P (1975) Synchronic variability and diachronic change in basic color terms. Lang Soc 4:257-270. https://doi.org/10.1017/S0047404500006667

Kemper S (2006) Language in adulthood. In: Bialystok E, Craik FIM (eds) Lifespan cognition: Mechanisms of change. Oxford University Press, New York, NY, pp. 223-238

Kemper S, Sumner A (2001) The structure of verbal abilities in young and older adults. Psychol Aging 16:312-322. https://doi.org/10.1037//08827974.16.2.312

Kerttula S (2002) English colour terms: Etymology, chronology, and relative basicness. Mémoires de la Société Néophilologique de Helsinki, Vol. LX. Société Néophilologique, Helsinki

Kharchenko VK (2009) Slovar' cveta: real'noe, potencial'noe, avtorskoe: svyše 4000 slov v 8000 kontekstax [Dictionary of color: Real, potential, heterodiegetic: More than 4,000 words in 8,000 contexts]. The Maxim Gorky Literature Institute, Moscow (in Russian)

Knoblauch K, Saunders F, Kusuda M, Hynes R, Podgor M, Higgins KE, de Monasterio FM (1987) Age and illuminance effects in the Farnsworth-Munsell 100-hue test. Appl Opt 26(8):1441-1448. https://doi.org/10.1364/AO.26.001441

Kul'pina VG (2001) Lingvistika cveta. Terminy cveta v pol'skom i russkom jazykax [Linguistics of color. Color terms in Polish and Russian]. Russkie slovari, Moscow (in Russian)

Kul'pina VG (2007) Sistema cvetooboznačenij russkogo jazyka [Color term system in Russian]. In: Vasilevich AP (ed) Naimenovanija cveta v indoevropejskix jazykax: Sistemnyj i istoričeskij analiz [Color terms in Indo-European languages: Systematic and historical analysis]. KomKniga, Moscow, pp. 126-184 (in Russian)

Kul'pina VG (2019) Lingvističeskaja cvetologija: ot istorii k sovremennosti cvetovyx konceptosfer [Linguistic colorlogy: from history to modernity of coloristic conceptual spheres]. MAKS Press, Moscow (in Russian)

Kuriki I, Lange R, Muto Y, Brown AM, Fikuda K, Tokunaga R, Lindsey DT, Uchikawa K, Shiori S (2017) The modern Japanese color lexicon. J Vis 17(3):1. https://doi.org/10.1167/17.3.1

Labov W (1990) The intersection of sex and social class in the course of linguistic change. Lang Var Change 2:205-254. https://doi.org/10.1017/ S0954394500000338

Labov W (2001) Principles of linguistic change. Social factors, vol. 2. Blackwell, Oxford

Laws G, Davies I, Corbett G, Jerrett T, Jerrett D (1995) Colour terms in Setswana: The effects of age and urbanization. Lang Sci 17:49-64. https://doi.org/ 10.1016/0388-0001(95)00002-D

Lillo J, Moreira H, del Tio LP, Alvaro L, del Carmen Duran M (2012) Basic color terms use by aged observers: lens aging and perceptual compensation. Span J Psychol 15:453-470. https://doi.org/10.5209/rev_SJOP.2012.v15.n2.38856

Lindenberger U, Baltes PB (1997) Intellectual functioning in old and very old age: Cross-sectional results from the Berlin Aging Study. Psychol Aging 12:410-432. https://doi.org/10.1037/0882-7974.12.3.410

Lindsey DT, Brown AM (2002) Color naming and the phototoxic effects of sunlight on the eye. Psychol Sci 13:506-512. https://doi.org/10.1111/14679280.00489

Lindsey DT, Brown AM (2014) The color lexicon of American English. J Vis 14(2):17. https://doi.org/10.1167/14.2.17

Lindsey DT, Brown AM (2019) Recent progress in understanding the origins of color universals in language. Curr Opin Behav Sci 30:122-129. https:// doi.org/10.1016/j.cobeha.2019.05.007

Margalef R (1958) Information theory in ecology. Gen Syst 3:36-71

McIntyre JS, Craik FIM (1987) Age differences in memory for item and source information. Can J Psychol 41(2):175-192. https://doi.org/10.1037/h0084154

Moss AES (1988) Russian blues and purples: A tentative hypothesis. Quinquereme 11:164-177

Moss A, Davies I, Corbett GG, Laws G (1990) Mapping Russian basic colour terms using behavioural measures. Lingua 82:313-332. https://doi.org/10.1016/ 0024-3841(90)90068-V

Mylonas D, MacDonald L (2010) Online colour naming experiment using Munsell colour samples. In: Proceedings of the 5th European Conference on Colour in Graphics, Imaging, and Vision (CGIV). IS\&T, Springfield, Joensuu, Finland, pp. 27-32

Mylonas D, MacDonald L (2016) Augmenting basic colour terms in English. Color Res Appl 41:32-42. https://doi.org/10.1002/col.21944 
Nasibullina FF (2010) Kolorativnaja leksika i ee funkcionirovanie v reklamax inter'era (na russkom i nemeckom jazykax) [Color lexicon and its functioning in interior advertisements (in Russian and German languages)]. Ph.D thesis, TGGPU, Kazan (in Russian)

Naveh-Benjamin M, Kilb A (2014) Age-related differences in associative memory: The role of sensory decline. Psychol Aging 29:672-683. https://doi.org/ $10.1037 / \mathrm{a} 0037138$

Niv Y, Daniel R, Geana A, Gershman SJ, Leong YC, Radulescu A, Wilson RC (2015) Reinforcement learning in multidimensional environments relies on attention mechanisms. J Neurosci 35:8145-8157. https://doi.org/10.1523/ JNEUROSCI.2978-14.2015

Paramei GV (2005) Singing the Russian blues: an argument for culturally basic color terms. Cross Cult Res 39:10-38. https://doi.org/10.1177/1069397104267888

Paramei GV (2007) Russian 'blues': Controversies of basicness. In: MacLaury RE, Paramei GV, Dedrick D (eds) Anthropology of color: Interdisciplinary multilevel modeling. John Benjamins, Amsterdam/Philadelphia, pp. 75-106

Paramei GV (2020) Color categorization: Patterns and mechanisms of evolution. In: Shamey R (ed.) Encyclopedia of color science and technology, 2nd edn. Springer, Berlin/Heidelberg. https://doi.org/10.1007/978-3-642-27851-8

Paramei GV, Bimler DL (2021) Language and psychology. In: Steinvall A, Street S (eds) A cultural history of colour. The Modern Age: From 1920 to present, vol. 6. Bloomsbury, London, pp. 117-134

Paramei GV, Griber YA, Mylonas D (2018) An online color naming experiment in Russian using Munsell color samples. Color Res Appl 43:358-374. https:// doi.org/10.1002/col.22190

Paramei GV, Oakley B (2014) Variation of chromatic discrimination across the lifespan. J Opt Soc Am A 31:A375-A384. https://doi.org/10.1016/S00426989(00)00205-4

Pérez-Carpinell J, Camps VJ, Trottini M, Pérez-Baylach C (2006) Color memory in elderly adults. Color Res Appl 31:458-467. https://doi.org/10.1002/col.20258

Pichler H, Wagner SE, Hesson A (2018) Old-age language variation and change: Confronting variationist ageism. Lang Linguist Compass 12(6):e12281. https://doi.org/10.1111/lnc3.12281

Rakhilina EV (2000/2008) Kognitivnyj analiz predmetnyx imen: semantika i sočetaemost' [Cognitive analysis of object names: Semantics and combinability]. Russkie slovari, Moscow (in Russian)

Rakhilina EV (2007a) Linguistic construal of colors: The case of Russian. In: MacLaury RE, Paramei GV, Dedrick D (eds) Anthropology of color: Interdisciplinary multilevel modeling. John Benjamins, Amsterdam/Philadelphia, pp. $363-377$

Rakhilina EV (2007b) O semantike prilagatel'nyx cveta [On semantics of color adjectives]. In: Vasilevich AP (ed) Naimenovanija cveta v indoevropejskix jazykax: Sistemnyj i istoričeskij analiz [Color terms in Indo-European languages: Systematic and historical analysis]. KomKniga, Moscow, pp. 29-39 (in Russian)

Rakhilina E, Paramei GV (2011) Colour terms: Evolution via expansion of taxonomic constraints. In: Biggam CP, Hough CA, Kay CJ, Simmons DR (eds) New directions in colour studies. John Benjamins, Amsterdam/Philadelphia, pp. 121-131

Romanik A (2019) Nominacje barw w rosyjskich magazynach modovych (prototypizacja $\mathrm{i}$ analiza strukturalna) [Names of colors in Russian fashion magazines (prototypisation and structural analysis)]. Prace Językoznawcze 21:211-221. https://doi.org/10.31648/pj.4697 (in Polish)

Ryabina E (2009) Sex-related differences in the colour vocabulary of Udmurts. Wiener elektronische Beiträge des Instituts für Finno-Ugristik (WEBFU). Internet journal. http://webfu.univie.ac.at/texte/12Ryabina.pdf. Accessed 15 Jul 2020

Safuanova OV, Korzh NN (2007) Russian color names. Mapping into a perceptual color space. In: MacLaury RE, Paramei GV, Dedrick D (eds) Anthropology of color: Interdisciplinary multilevel modeling. John Benjamins, Amsterdam/ Philadelphia, pp. 55-74

Samarina LV (2007) Gender, age, and descriptive color terminology in some Caucasus cultures. In: MacLaury RE, Paramei GV, Dedrick D (eds) Anthropology of color: Interdisciplinary multilevel modeling. John Benjamins, Amsterdam/Philadelphia, pp. 457-466

Samoilova TA, Griber YA (2019) Komp'ûternaâ očistka dannyx v svobodnom èksperimente po izučeniû cvetonaimenovanij Computer data cleaning in an unconstrained color naming experiment]. Social'nye transformacii 30:172-179. (in Russian)811.161.1'373.46

Schacter DL, Osowiecki D, Kaszniak AW, Kihlstrom JF, Valdiserri M (1994) Source memory: Extending the boundaries of age-related deficits. Psychol Aging 9:81-89. https://doi.org/10.1037/0882-7974.9.1.81

Schmid HJ (2017) A framework for understanding linguistic entrenchment and its psychological foundations. In: Schmid HJ (ed) Language and the human lifespan series. Entrenchment and the psychology of language learning: How we reorganize and adapt linguistic knowledge. Walter de Gruyter, Berlin, pp. 9-35

Simpson J, Tarrant AWS (1991) Sex- and age-related differences in colour vocabulary. Lang Speech 34:57-62. https://doi.org/10.1177/002383099103400104
Smith M (2000) Color terminology in American English: Its diachronic and synchronic heterogeneity. Master's Thesis, Swarthmore College, Swarthmore, PA Stanulewicz D (2010) Polish terms for 'blue' in the perspective of Vantage Theory. Lang Sci 32:184-195. https://doi.org/10.1016/j.langsci.2009.10.004

Stefanov SI (2015) Nazvaniâ cveta i ego ottenkov. Tolkovyj slovar'-spravočnik. Bolee 2000 terminov s anglijskimi èkvivalentami [Names of colors and their shades. The explanatory dictionary with definitions. More than 2000 terms with English equivalents]. LENAND, Moscow (in Russian)

Strauss W, Howe N (1991) Generations: The history of America's future, 1584 to 2069. Harper Perennial, New York, NY

Strauss W, Howe N (2000) Millennials rising: The next great generation. Vintage Original, New York, NY

Sun C, Charykova ON (2016) Sistema kolorativov v reklamnyx katalogax dekorativnoj kosmetiki [A system of coloratives in advertising catalogues of decorative cosmetics]. Vestnik Voronezhskogo Gosudarstvennogo Universiteta. Seriya Lingvistika i Mezhkulturnaya Kommunikaciya 3:30-33 (in Russian)

Tagliamonte SA, D'Arcy A (2009) Peaks beyond phonology: Adolescence, incrementation, and language change. Language 85:58-108. https://doi.org/ 10.1353/lan.0.0084

Teixeira M P (2019) As cores en galego: As laranxas e as violetas pertencen só ao mundo vexetal [Colors in Galician: Orange and purples belong only to the vegetable worlds]. In: Marques MA, Sánchez Rei XM (eds) Estudos atuais de linguística galego-portuguesa. Laiovento, Santiago de Compostela, pp. 295-332 (in Galician)

Thornton R, Light LL (2006) Language comprehension and production in normal aging. In: Birren JE, Warner Schaie K (eds) Handbook of the psychology of aging. Elsevier, Burlington, MA, pp. 262-287

Vasilevich AP (1981) Oboznačenie cveta v sovremennom russkom jazyke [Color terms in the modern Russian language]. Unpublished manuscript. INION USSR No. 7699, Moscow (in Russian)

Vasilevich AP (2004) O sovremennyx tendencijax razvitija leksiki cvetooboznačenija [On current tendencies in development of the color-term vocabulary]. In Vasilevich AP (ed) Problemy cveta v ètnolingvistike, istorii I psixologii. Kruglyj stol [Problems of color in ethnolinguistics, history and psychology. Round table], Moscow, pp. 5-14 (in Russian)

Vasilevich AP, Kuznecova SN, Mishchenko SS (2005) Cvet i nazvanija cveta v russkom jazyke [Color and color terms in the Russian language]. LCI Publisher, Moscow (in Russian)

Vasmer M (1953) Russisches etymologisches Wörterbuch I-III. Carl Winter Universitätsverlag, Heidelberg, https://gufo.me/dict/vasmer/\%D0\%B1\%D1\% $83 \% \mathrm{D} 1 \% 80 \% \mathrm{D} 1 \% 8 \mathrm{~B} \% \mathrm{D} 0 \% \mathrm{~B} 9$

Vejdemo S (2017) Triangulating perspectives on lexical replacements: From predictive statistical models to descriptive linguistics. Ph.D Thesis, Stockholm University

Vejdemo S (2018) Lexical change often begins and ends in semantic peripheries. Evidence from color linguistics. Pragmat Cogn 25:50-85. https://doi.org/ 10.1075/pc.00005.vej

Villanueva Gesteira MD (2009) O campo semántico das cores visto por tres xeracións [The semantic domain of colors viewed by three generations]. Estudos de Lingüística Galega 1:169-188 (in Galician)

Ward Jr JH (1963) Hierarchical grouping to optimize an objective function. J Am Stat Assoc 58:236-244. https://doi.org/10.1080/01621459.1963.10500845

Werner JS, Schefrin BE (1993) Loci of achromatic points throughout the life span. J Opt Soc Am A 10:1509-1516. https://doi.org/10.1364/josaa.10.001509

Wierzbicka A (1990) The meaning of color terms: Semantics, culture, and cognition. Cogn Linguist 1:99-150. 10.1515/cogl.1990.1.1.99

Wrzus C, Hänel M, Wagner J, Neyer FJ (2013) Social network changes and life events across the life span: A meta-analysis. Psychol Bull 139:53-80. https:// doi.org/10.1037/a0028601

Wulff DU, De Deyne S, Jones MN, Mata R, The Aging Lexicon Consortium (2019) New perspectives on the aging lexicon. Trends Cogn Sci 23:686-698. https:// doi.org/10.1016/j.tics.2019.05.003

Wuerger S (2013) Colour constancy across the life span: Evidence for compensatory mechanisms. PLoS ONE 8(5):e63921. https://doi.org/10.1371/ journal.pone.0063921

Yeom DJ, Kim JH (2011) Comparative evaluation of species diversity indices in the natural deciduous forest of Mt. Jeombong. Forest Sci Technol 7:68-74. https://doi.org/10.1080/21580103.2011.573940

Zaręba A (1954) Nazwy barw w dialektach i historii języka polskiego [Color names in dialects and history of the Polish language]. Ossolińskich, Wrocław (in Polish)

Zaslavsky N, Kemp C, Tishby N, Regier T (2020) Communicative need in colour naming. Cogn Neuropsychol 37:312-324. https://doi.org/10.1080/ 02643294.2019.1604502

Zickuhr K, Madden M (2012) Older adults and internet use. Pew Research Center Internet \& Technology. http://www.pewinternet.org/2012/06/06/older-adultsand-internet-use/ Accessed on 15 Jul 2020 


\section{Acknowledgements}

YG was supported by the Grant 17-29-09145 of the Russian Foundation for Basic Research. DM was supported in part by the Doctoral Training Grant EP/M506448/11573073 from the Engineering and Physical Sciences Research Council (UK) and by the FY22 TIER 1 Seed Grant from Northeastern University (US). The authors are indebted to Carole Biggam for invaluable discussions of linguistic innovations in Russian color terms. We thank Adam Głaz for his help in retrieving some rare literature sources in Polish and Paula Teixeira Moláns for providing us with sources on Galician color terms and translation of the publications from Galician. Support of Tatjana Samoilova, Alexei Delov, and Karina Zygankova in data processing is gratefully appreciated. The authors are also grateful to all participants for their time and good will.

\section{Competing interests}

The authors declare no competing interests.

\section{Ethical approval}

Participants were not required to identify themselves, apart from their age, gender and other demographic characteristics indicated above, so the collected data were not linked to individuals. The experimental procedure complied with the ethical principles of the Declaration of Helsinki.

\section{Informed consent}

Participation was voluntary, did not put any strain of power on the participants. They were informed that they could withdraw from the experiment at any time.

\section{Additional information}

Supplementary information The online version contains supplementary material available at https://doi.org/10.1057/s41599-021-00943-2.

Correspondence and requests for materials should be addressed to Yulia A. Griber.

Reprints and permission information is available at http://www.nature.com/reprints

Publisher's note Springer Nature remains neutral with regard to jurisdictional claims in published maps and institutional affiliations.

\begin{abstract}
cc (i) Open Access This article is licensed under a Creative Commons Attribution 4.0 International License, which permits use, sharing, adaptation, distribution and reproduction in any medium or format, as long as you give appropriate credit to the original author(s) and the source, provide a link to the Creative Commons license, and indicate if changes were made. The images or other third party material in this article are included in the article's Creative Commons license, unless indicated otherwise in a credit line to the material. If material is not included in the article's Creative Commons license and your intended use is not permitted by statutory regulation or exceeds the permitted use, you will need to obtain permission directly from the copyright holder. To view a copy of this license, visit http://creativecommons.org/ licenses/by/4.0/.
\end{abstract}

(C) The Author(s) 2021 